\title{
12. Yabancı dil olarak Türkçe ders materyallerinde Türk ve Türkiye imajına ilişkin unsurlar
}

\section{Elif AKTAŞ1}

\begin{abstract}
APA: Aktaş, E. (2021). Yabancı dil olarak Türkçe ders materyallerinde Türk ve Türkiye imajına ilişkin unsurlar. RumeliDE Dil ve Edebiyat Araştırmaları Dergisi, (22), 232-257. DOI: 10.29000/rumelide.890442.
\end{abstract}

\section{$\ddot{\mathbf{O} z}$}

Yabancı dil olarak Türkçe öğretiminin en önemli boyutlarından biri kültür aktarımıdır. Bu çalışmanın amacı yabancı dil olarak Türkçe ders materyallerinde Türk ve Türkiye imajının nasıl betimlendiğini belirlemektir. İmaj bir kişinin, kurumun, nesnenin, toplumun veya ülkenin sahip olduğu tüm değerlerle ilgili unsurların algılanış biçimidir. Nitel bir anlayışla desenlenen çalışmada doküman inceleme yöntemi kullanılmıştır. Araştırmanın inceleme nesnelerini İstanbul TÖMER, Yeni Hitit ve Yedi İklim yabancı dil olarak Türkçe öğretim setleri (30 kitap) oluşturmaktadır. Araştırmanın veri toplama aracı, literatür taranarak hazırlanan ve uzman görüşü alınıp son şekli verilen 'Türk/Türkiye İmajı Belirleme Formu'dur. Formda imaj belirlemek için altı ana kategoriye yer verilmiştir: Gastronomi, mekân, kültürel unsurlar (dinî ve millî), meslekler, ünlü kişiler/kurumlar, edebiyat/sanat/spor ile ilgili imajlar. Veriler, içerik analizi yöntemiyle çözümlenmiştir. Çalışmanın sonunda İstanbul TÖMER ders ve çalışma kitaplarının Türk imajı ile ilgili daha fazla sayıda ögeye yer verdiği tespit edilmiştir. Bunun yanı sıra tüm kitaplarda ve tüm düzeylerde yeme-içme ve mekân ile ilgili imajlar kendine daha fazla yer bulmuştur. Tüm öğretim setlerinde özellikle meslekler ile ilgili imajların eksik olduğu sonucuna ulaşılmıştır. Modern ve popüler mesleklerin daha çok yer aldığı kitaplarda geleneksel ve Türk kültürüne özgü meslekleri yansıtmada Yedi İklim öğretim setinin daha başarılı olduğu görülmüştür. Kültürel unsurlarla ilgili imajların ise İstanbul TÖMER öğretim setinde; edebiyat, sanat ve sporla ilgili imajların da Yedi İklim öğretim setinde daha fazla yer aldı̆̆ı tespit edilmiştir.

Anahtar kelimeler: Yabancı dil olarak Türkçe öğretimi, ders materyalleri, kültürel ögeler, Türk imajı, Türkiye imajı.

\section{Elements related to Turk and Turkey's image in Turkish as a foreign language textbooks}

\begin{abstract}
One of the most important dimensions of teaching Turkish as a foreign language is cultural transfer. The aim of this study is to describe the image of Turkey and Turk in Turkish as a foreign language textbooks. Document analysis method was used in the study, which was designed with a qualitative approach. The sample of the research are İstanbul TÖMER, Yeni Hitit and Yedi İklim Turkish textbooks (30 books). In the research, 'Turkish/Turkish image determination form' was used as a data collection tool, prepared by scanning the literature and receiving expert opinion. Six main categories are used to determine the image in the form: images related to gastronomy, place, cultural elements (religious and national), professions, famous people / institutions, literature / art
\end{abstract}

Doç. Dr., Alanya Alaaddin Keykubat Üniversitesi, Eğitim Fakültesi, Türkçe ve Sosyal Bilimler Eğitimi Bölümü, Türkçe Eğitimi ABD (Antalya, Türkiye), elif.aktas@alanya.edu.tr, ORCID ID: 0ooo-ooo1-5573-2274 [Araştırma makalesi, Makale kayıt tarihi: 05.02.2021-kabul tarihi: 20.03.2021; DOI: 10.29000/rumelide.890442]

\section{Adres $\mid$ Address}

RumeliDE Dil ve Edebiyat Araştırmaları Dergisi Osmanağa Mahallesi, Mürver Ciçç̆i Sokak, No:14/8 Kadıköy - İSTANBUL / TÜRKIYE 34714 e-posta: editor@rumelide.com

RumeliDE Journal of Language and Literature Studies Osmanağa Mahallesi, Mürver Çiçeği Sokak, No:14/8

Kadıköy - ISTANBUL / TURKEY 34714

e-mail: editor@rumelide.com

tel: +90 505 7958124, +90 216773 o 616 phone: +90 505 7958124, +90 2167730616 
/ sports. The datas were analyzed by content analysis method. At the end of the study, it was determined that Istanbul TÖMER textbooks and workbooks included more elements about the Turkish image. In addition, images related to gastronomy and place found in all books and at all levels more. It was concluded that images of especially professions were missing in all teaching sets. It has been observed that the Yedi İklim teaching set is more successful in reflecting the traditional and Turkish culture-specific professions in the books that include more modern professions. Images of cultural elements are included in the Istanbul TÖMER teaching set; It has been determined that the images related to literature, art and sports are also included in the Yedi İklim teaching set.

Keywords: Teaching Turkish as a foreign language, textbooks, cultural elements, the image of Turk, the image of Turkey.

\section{Giriş}

Yabancı dil olarak Türkçe öğretiminde en sık kullanılan materyallerin başında gelen ders kitaplarında dile ait birtakım kural ve bilgilerin verilmesinin yanında yaşam ve deneyim alanları çerçevesinde kültürel ögeler de aktarılmalıdır. Bu sayede bir yandan öğrenilen dilin kültüründeki yaşam kahıpları yansıtılırken bir yandan da kültürel çeşitlilik aktarılır (Özışık, 2004: 98). Yabancı dil öğretiminde sıkça kullanılan ders kitapları, aynı zamanda kültür aktarımının temel unsurlarından biridir. Haley ve Austin (2013), yabancı dil öğretiminde ders kitaplarının hedef dilin kültürüne ait unsurlar içermesi ve bununla ilgili önyargılardan uzak bir şekilde etkinlikler sunması gerektiğini ifade eder.

Dil ve kültür, birbirlerinden ayrılmaz iki unsurdur. Bu açıdan dil öğretiminde kültür aktarımının da yapılması yadsınamaz. Byram \& Morgan'a göre (1994) göre kültürel bağlamdan kopuk bir dil öğretimi başarıya ulaşamaz. Bu yüzden yabancı dil/ikinci dil öğrenenlerin mutlaka hedef dile ait kültürü de edinmesi gerekir.

Avrupa Dilleri Öğretimi Ortak Çerçeve metninde (CEFR, 2020) dil eğitiminin öncelikli hedeflerinden birinin o dile ait sosyo-kültürel değerleri aktarmak olduğu ifade edilmiştir. Buna göre dil öğretimi esnasında aşağıdaki ögeler de hedef kitleye kazandırılmalıdır:

- Günlük yaşamla ilgili unsurlar (Yiyecek-içecekler, sofra adabı, millı̂ bayramlar, çalışma saatleri, boş zaman etkinlikleri, spor, okuma alışkanlıkları, medya vb.),

- Yaşam koşulları (bölgesel, sınıfsal ve etnik farklılıklar, barınma imkânları, sosyal yardım vb.),

- Bireyler arası ilişkiler (sınıflar arası ilişkiler, cinsler arası ilişkiler, aile bireyleri arasındaki ilişkiler, nesiller arası ilişkiler, iş ortamındaki ilişkiler, toplum ile resmî görevliler arasındaki ilişkiler, ırk ve toplum ilişkileri, siyasî ve dinî gruplar arasındaki ilişkiler vb.),

- Değerler, inanç ve tutumlar (Sosyal sınıf, meslekler, kurumlar, gelenekler, ikonlaşmış tarihî kişi ve olaylar, azınlıklar (etnik ve dinî), millî kimlik, ideolojiler, yabancı üniversiteler ve kişiler, sanat-müzik, görsel sanatlar, edebiyat, drama, popüler müzik, mizah ile ilgili unsurlar vb.),

- Âdetler (misafir ağırlama, hediye, ikram, yiyecek ve içecekler, davranış ve söyleyiş âdetleri, ziyaretler, vedalaşma vb.),

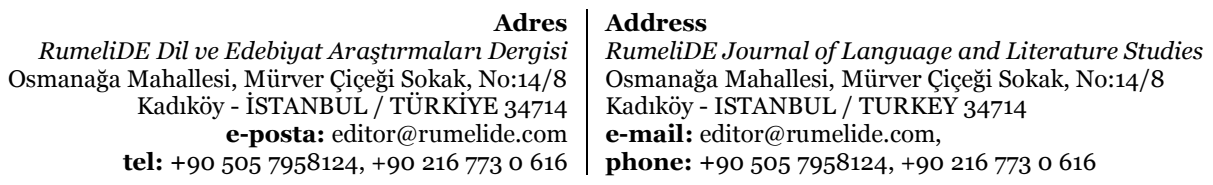


- Törenler (dinî tören ve ritüeller, doğum, ölüm, evlilik, halka açlk gösteri ve törenlerde seyirci davranışları, kutlamalar, festivaller, danslar vb.)

CEFR'e göre (2020) yabancı dil öğretiminde kültür aktarımı, öğrencileri hedef kültüre ait sosyal yaşama hazırlayıcı bir rol üstlenmektedir. Bu sayede öğrenenler, hedef kültüre ait toplumun yapısını tanıma olanağı yakalamakta, sosyal hayatta karşılaşabileceği iletişim sorunlarını da en aza indirgemektedir.

Yabancı dil öğretiminde kültür aktarımı, o dili öğrenenlere farklı bir toplumda yaşama olană̆ı sunmakta ayrıca insanları sosyalleşmeye ve hoşgörülü olmaya da hazırlamaktadır. Yabancı dil öğretiminde başarılı olmak için kültür aktarımı mutlaka yapılmalıdır (Tseng, 2002). Çünkü yabancı bir dil öğrenme işi, aynı zamanda o kültürü de anlama/tanıma işi demektir (Tapan, 1990: 55). Yabancı dil öğretiminde kültürel unsurlara yer verildiğinde kişi kendi yaşantısından farklı bir yaşam tarzını öğreneceği için motivasyonu da artar, böylece kendi kültürü ile öğrenmekte olduğu kültürü karşılaştırıp yaşamını zenginleştirme firsatı elde eder (Okur ve Keskin, 2013: 1626). Nitekim yabancı dili öğrenen kişinin o dile ait kültürü de öğrenmesinin iletişim becerilerini geliştirdiği, dil öğrenmeye karşı bir farkındalık oluşturduğu ve yabancı kültürdeki insanlara karşı olumlu tutum geliştirdiği belirlenmiştir (Cortazi \& Jin, 1999: 197). Bu yüzden yabancı dil öğreniminde sadece dil bilgisi ve sözcük öğretimi üzerinde durulmamalı; hedef kültürün dünyaya bakış açısı ve değer sistemi de aktarılmalıdır (Demir ve Açık, 2011: 55). Yabancı bir dilde pek çok kelime öğrenmek ve o dile ait kuralları bilmek, o dili öğrenmek demek değildir. Bir dil öğrenmek isteyen kişi; o dilin konuşma kalıplarını, o dili konuşan insanların düşünme biçimlerini ve dilin hangi ortamda nasıl konuşulması gerektiğini de bilmeli ayrıca o dilin kültürü ve edebiyatı hakkında da fikir sahibi olmalıdır. Hedef dilde başarılı bir şekilde konuşmak ve yazmak için, o dilin kültürel bağlamını da bilmek gereklidir. Yabancı dil öğretiminin amacına ulaşması için öğrencilere, hedef dilin toplumsal ve kültürel yapısını, o toplumun değer yargılarını ve dünya görüşünü yansıtan öğretim materyalleri hazırlanmalı ve kullanılmalıdır (Okur ve Keskin, 2013: 1624). Yabancı dil öğretiminde kültürel aktarımın gerçekleşmesi için şu hususlara da dikkat edilmelidir (Songül, 1991):

- Hedef dile ait ülkenin coğrafî özelliklerini bilmek,

- İlgili ülkenin tarihî olaylarını ve kişilerini bilmek,

- Gastronomi, edebiyat, sanat, spor ve mimarî ile ilgili unsurlarını tanımak,

- Alışveriş, tanışma gibi günlük konuşma dilinde yer alan kültürel kalıpları bilmek,

- Evlilik, eğitim, politika alanındaki kültürel kalıpları bilmek,

- Günlük olaylara uygun kalıpları bilmek ve ona göre davranmak,

- Hedef kültüre ait mimikleri tanımak ve yerli yerinde kullanmak,

- Hedef kültürdeki etnik grupları tanımak.

Yabancı bir dilde iletişim kurabilmek için hedef dilin kültürünü de öğrenmek şarttır (Demircan, 1990: 26). Yabancı dil öğrenen kişi aynı zamanda yeni bir kültür öğrenir. Bu nedenle dil öğretimi en güzel o kültürün anlatıldığı, yansıtıldığı ve yaşandığı/yaşatıldığı ortamlarda gerçekleşir. Kültürü oluşturan

\footnotetext{
Adres
RumeliDE Dil ve Edebiyat Araştırmaları Dergisi Osmanağa Mahallesi, Mürver Ciçeği Sokak, No:14/8 Kadıköy - İSTANBUL / TÜRKIYE 34714 e-posta: editor@rumelide.com tel: +90 505 7958124, +90 2167730616

Address

RumeliDE Journal of Language and Literature Studies

Osmanağa Mahallesi, Mürver Çiçeği Sokak, No:14/8

Kadıköy - ISTANBUL / TURKEY 34714

e-mail: editor@rumelide.com,

phone: +90 5057958124 , +90 2167730616
} 
ögeler çok geniş ve çeşitlidir. Yabancılara Türkçe öğretimi sürecinde de Türk kültürünü yansitan tüm unsurların hem ders materyallerinde hem de eğitim ortamlarında etkili bir şekilde kullanılması gereklidir. Bu doğrultuda eğitim ortamının kültürel ögelerle donatılması, Türkçeyi yabancı dil olarak öğrenenleri Türk kültürü ile çokça karşılaştırmak için etkili bir araç olarak kullanılabilir (Memiş, 2016: 612). Yabancı dil olarak Türkçe öğretiminde her şeyden evvel kültür aktarımı yapılmalı, öğrencilere Türk ve Türkiye imajını yansıtan örnekler sunulmalıdır. Yabancı dil öğrenmeye yönelik materyal hazırlanırken o kültüre ait ögeleri tanıtacak temalar, metinler ve görseller seçilmeli ve kullanılmalıdır. Bu durum; öğrencilerin hedef dilde karşılarına çıkan yeni sözcük, kavram ve yapıları daha basit bir şekilde öğrenmelerini sağlayacaktır (Yaylı ve Yaylı, 2009: 36). Kültüre ait unsurlara dil öğretiminde ne kadar çok yer verilirse o kadar başarılı ve kalıcı sonuçlar elde edilir (Mutlu ve Set, 2020: 94). Yabancı dil olarak Türkçe öğretim sürecinde dinleme, konuşma, okuma ve yazma gibi dil becerilerinin geliştirilmesinde, sözcük öğretiminde ya da dil bilgisi öğretiminde eş zamanlı olarak kültür aktarımı da yapılmasına özen gösterilmelidir (Akkaya, 2013).

TDK Türkçe Sözlük’te (2011) ‘genel görünüş, izlenim’ anlamına gelen imaj; kişiler, hizmetler, ürünler, olaylar, fikirler, kurum-kuruluşlar, toplumlar, ülkeler ve devletler hakkında edinilmiş olan algl, izlenim, genel kanı ve zihinde tasarlanan kurgudur (Karagöz Yerdelen, 2017: 44). Başka bir deyişle imaj, kısa ve uzun vadede bir kişinin, kurumun, nesnenin, toplumun veya ülkenin sahip olduğu tüm değerlerle ilgili unsurların algılanış biçimidir (Gültekin, 2005: 127). İmaj, karşı tarafın durumunu ortaya koyduğu kadar alımlayıcının yani imaj yapıcının kendi görüş ve niyetlerini de yansıtır. Bu açıdan imaj, genel kanıya varanın algısına göre gerçekliğe yakın olabilir ya da gerçeklikten tamamen uzaklaşabilir.

İmaj ve kimlik, tanıma ve tanımlama bileşenleri içerisinde değerlendirilmektedir. Buna göre tanıma ve tanımlanma; bireyin, ulusun ya da ülkenin başkaları tarafından nasıl tanındığı ya da kendini nasıl tanımladığını ortaya koyar. Bunun aracı da dil ve kültürdür. Bu nedenle özellikle dil öğretiminde kültürün göz ardı edilmemesi ve kültür aktarımının nasıl yapıldığına da dikkat edilmesi gerekmektedir. Çünkü bu uluslararası bir imaj meselesidir. Uluslararası imaj, öteki ulusların zihnindeki ulusal siz algısıdır, yani onların bizim ulusumuz hakkındaki kabulleri ve düşünceleridir. Doğal olarak her ulus, kendi biz algısının, ulusal kimliğinin kendi isteği doğrultusunda şekillenmesini ister. İmaj, retorik söylemlerin ve bilimsel çalışmaların kamuya sunduğu bilgilerin dışında, ülkelerin kendilerinin sahip olduklarına inandıkları imgelem-değerlerden oluşur. İmaj-kod adı verilen bu imgelem-değerler, gerçeğe ne kadar yakın olursa o ölçüde inandırıcı, etkileyici ve kalıcı olacaktır (Kaleağası, 2003’ten akt. Karagöz Yerdelen, 2017: 48). Uluslararası imajı temsil eden görüntünün de bizim istediğimiz gibi olması son derece önemlidir. Bunu başarabilmek için öncelikle kendi biz algımızı doğru ve net olarak belirlememiz gerekmektedir. Meseleye dil öğretimi açısından bakıldığında ise özellikle yabancılara Türkçe öğretimi kapsamında hazırlanan materyallerin imaj meselesini doğru bir şekilde yansıtması gerekmektedir. Bu açıdan ders materyallerinde Türk ve Türkiye imajının Türkçe öğrenmek isteyen bir yabancıya nasıl sunulduğu, kültür aktarımı ve dil öğretimi açısından son derece önemlidir.

İlgili literatürde yabancı dil olarak Türkçe ders kitaplarında kültür aktarımını inceleyen çeşitli çalışmalar mevcuttur. Yapılan araştırmalar, farklı düzeylerde ve farklı yayınevlerine ait ders kitaplarında kültürel ögelerin aktarımını incelemeye yöneliktir. Bu araştırmaların çoğu ders kitaplarındaki kültürel ögelerin aktarımının yetersiz olduğunu ortaya koymaktadır (Okur ve Keskin, 2013; Kutlu, 2014; Karababa ve Üstünsoy Taşkın, 2012; Bayraktar, 2015). Ancak ilgili araştırmalar, tek bir yayınevine ya da tek bir seviyeye (temel, orta ya da ileri düzey) odaklanmıştır (Ülker, 2007; Sever,

\begin{tabular}{r|l} 
Adres & Address \\
RumeliDE Dil ve Edebiyat Arastirmaları Dergisi & RumeliDE
\end{tabular}

Osmanağa Mahallesi, Mürver Çiçeği Sokak, No:14/8 Osmanağa Mahallesi, Mürver Çiçeği Sokak, No:14/8

Kadıköy - İSTANBUL / TÜRKIYE 34714 Kadıköy - ISTANBUL / TURKEY 34714

e-posta: editor@rumelide.com

e-mail: editor@rumelide.com

tel: +90 505 7958124, +90 216773 o 616 phone: +90 505 7958124, +90 2167730616 
2019; Mutlu ve Set, 2020; İşçi, 2012; Erdem, Gün ve Karateke, 2015). Bu çalışmanın amacı, yabancı dil olarak Türkçe ders kitaplarında yer alan Türk ve Türkiye imajını tüm öğretim setleri ve tüm düzeyler açısından betimlemektir. Bu amaçla çalışmada, yabancı dil olarak Türkçe öğretimi kapsamında yaygın bir şekilde kullanılan Türkçe ders materyalleri (İstanbul TÖMER, Yedi İklim ve Yeni Hitit TÖMER öğretim setleri içerisindeki 30 adet ders ve çalışma kitabı), bu imajı yansıtan ögeler açısından incelenmeye çalışılmıştır. Araştırmada yabancı dil olarak Türkçe öğrenenlerin nasıl bir Türk ve Türkiye imajıyla karşılaştıklarını belirlemek amacıyla aşağıdaki alt problemlere yanıt aranmıştır:

1. Yabancı dil olarak Türkçe ders materyallerinde gastronomi/yeme-içme ile ilgili imajlar nedir?

2. Yabancı dil olarak Türkçe ders materyallerinde mekân ile ilgili imajlar nedir?

3. Yabancı dil olarak Türkçe ders materyallerinde kültürel unsurlar (dinî ve millî) ile ilgili imajlar nedir?

4. Yabancı dil olarak Türkçe ders materyallerinde meslekler ile ilgili imajlar nedir?

5. Yabancı dil olarak Türkçe ders materyallerinde ünlü kişiler/kurumlar ile ilgili imajlar nedir?

6. Yabancı dil olarak Türkçe ders materyallerinde edebiyat/sanat/spor ile ilgili imajlar nedir?

\section{Yöntem}

Yabancı dil olarak Türkçe ders materyallerinde Türk ve Türkiye imajını betimlemeyi amaçlayan bu çalışma, nitel bir araştırma özelliği göstermektedir. Nitel araştırmalar verilerin kod ve kategorilere dayalı olarak çözümlenmesini sağlar (Merriam, 2013). Gözlem, görüşme ve doküman analizi gibi nitel veri toplama yöntemlerinin kullanıldığı nitel araştırmalarda, olayların ve algıların gerçekçi ve bütüncül bir biçimde ortaya konmasına yönelik bir süreç izlenmektedir (Yıldırım ve Şimşek, 2016). Bu çalışmada da veri toplama yöntemi olarak doküman analizi tercih edilmiştir. Doküman analizi, yazılı belgeleri titizlikle ve sistematik olarak analiz etmek amacıyla kullanılan bir nitel araştırma yöntemidir (Wach, 2013). Mevcut kayıt ya da belgelerin, veri kaynăg 1 olarak sistemli bir şekilde incelenmesi anlamına gelen doküman analizi; ilgili belgelerin bulunması, incelenmesi ve senteze varılması aşamalarından oluşmaktadır (Karasar, 2007). Bu araştırmada da yabancı dil olarak Türkçe ders kitaplarında yer alan Türk ve Türkiye imajına ilişkin unsurlar, doküman incelemesi yöntemiyle incelenmiştir. Bu aşamada öncelikle araştırmaya dâhil edilecek materyaller belirlenmiş, ardından bu materyallerdeki Türk ve Türkiye imajına ilişkin unsurlar tespit edilmiş ve elde edilen sonuçlar benzer çalışmalarla kıyaslanıp tartışılmıştır.

\section{Veri toplama aracı}

Nitel araştırmada veriler; gözlem, görüşme ve dokümanlar yoluyla elde edilir (Berg \& Lune, 2015; Merriam, 2013). Araştırmada İstanbul TÖMER (2016), Yeni Hitit (2013) ve Yedi İklim (2015) yayınevlerine ait Türkçe öğretim setleri, Türk ve Türkiye imajını yansıtma durumu açısından incelenmiştir. Dolayısıyla söz konusu ders kitapları bu araştırmada veri toplama aracı olarak kullanılmıştır. Bununla birlikte kitaplarda Türk ve Türkiye imajının belirlenmesi için ilgili literatür taranarak oluşturulan 'Türk ve Türkiye İmajı Belirleme Formu' kullanılmıştır. Formun oluşturulmasında Türkçe eğitimi alan uzmanlarının $(n=3)$ görüşlerinden faydalanılmıştır. Literatür

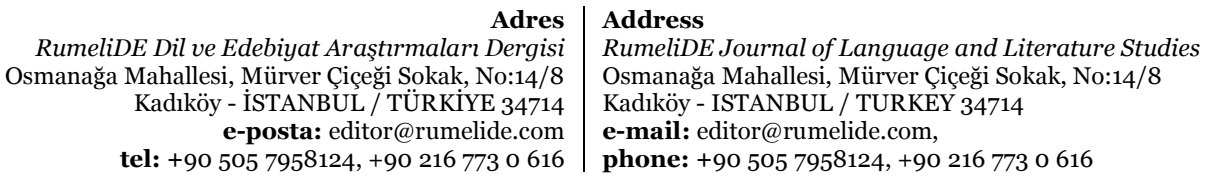


taranarak ve uzman görüşü alınarak formun geçerlilik ve güvenirliği sağlanmaya çalışılmıştır. Bu doğrultuda araştırma kapsamındaki ders kitaplarında Türk ve Türkiye imajının nasıl betimlendiği belirlenmeye çalışılmıştır. Araştırmanın inceleme nesnesi olan ders kitaplarının künyesi ise Tablo 1'de gösterilmiştir:

\begin{tabular}{|c|c|c|c|}
\hline Yayınevi & Yayın yılı & Kitap türü & Seviye \\
\hline \multirow{2}{*}{ İstanbul TÖMER } & \multirow{2}{*}{2016} & Ders kitabı & $\mathrm{A} 1, \mathrm{~A} 2, \mathrm{~B} 1, \mathrm{~B} 2, \mathrm{C} 1, \mathrm{C} 2$ \\
\hline & & Çalışma kitabı & $\mathrm{A} 1, \mathrm{~A} 2, \mathrm{~B} 1, \mathrm{~B} 2, \mathrm{C} 1, \mathrm{C} 2$ \\
\hline \multirow{2}{*}{ Yedi İklim } & \multirow{2}{*}{2015} & Ders kitabı & $\mathrm{A} 1, \mathrm{~A} 2, \mathrm{~B} 1, \mathrm{~B} 2, \mathrm{C} 1, \mathrm{C} 2$ \\
\hline & & Çalışma kitabı & $\mathrm{A} 1, \mathrm{~A} 2, \mathrm{~B} 1, \mathrm{~B} 2, \mathrm{C} 1, \mathrm{C} 2$ \\
\hline \multirow{2}{*}{ Yeni Hitit } & \multirow{2}{*}{2013} & Ders kitabı & $1(\mathrm{~A} 1, \mathrm{~A} 2), 2(\mathrm{~B} 1), 3(\mathrm{~B} 2, \mathrm{C} 1)$ \\
\hline & & Çalışma kitabı & $1(\mathrm{~A} 1, \mathrm{~A} 2), 2(\mathrm{~B} 1), 3(\mathrm{~B} 2, \mathrm{C} 1)$ \\
\hline
\end{tabular}

Tablo 1. Araştırmanın inceleme nesnelerini oluşturan ders kitapları

Tablo 1'e göre tüm yayınevleri kapsamında 30 adet ders ve çalışma kitabı, bu araştırmanın inceleme nesnelerini oluşturmaktadır. Bunun yanı sıra araştırmada başka veri toplama aracı olarak ilgili literatür taranarak hazırlanan ve uzman görüşü alınıp ön inceleme yapılarak son şekli verilen 'Türk/Türkiye İmajı Belirleme Formu' kullanılmıştır. Form, aşağıda belirtilen 6 ana başlıktan oluşmaktadır:

- Gastronomi ile ilgili imajlar,

- Mekân ile ilgili imajlar,

- Kültürel unsurlar (dinî ve millî) ile ilgili imajlar,

- Meslekler ile ilgili imajlar,

- Ünlü kişiler/kurumlar ile ilgili imajlar,

- Edebiyat/sanat/spor ile ilgili imajlar (CEFR, 2020; Erdem, Mutlu ve Set, 2020; Gün ve Karateke, 2015; Ökten ve Kavanoz, 2014; Okur ve Keskin, 2013; Aksoy, 2011; Ülker, 2007; Özışık, 2004).

\section{Verilerin analizi}

Miles ve Huberman'a (1994) göre nitel veri analizi; verilerin azaltılması, sunulması ve sonuçların ortaya konması aşamalarından oluşmaktadır. Toplanan verileri analiz ederken betimsel ve içerik analizi dışında söylem analizi, doküman analizi gibi teknikler de kullanılmaktadır (Yıldırım ve Şimşek, 2016). Bu araştırma kapsamında veri analizi, ham verilerin okuyucunun anlayabileceği ve gerek duyduğunda kullanabileceği bir şekle dönüştürülmesi anlamına gelen betimsel analiz tekniği kullanılarak yapılmıştır. Betimsel analizde amaç, elde edilen bulguları düzenleyerek ve yorumlayarak okuyucuya sunmaktır. Bu doğrultuda veriler, önce sistematik ve açık bir biçimde betimlenmektedir. Ardından ise bu betimlemeler açıklanıp yorumlanarak birtakım sonuçlara ulaşılmaktadır (Yıldırım ve Şimşek, 2016). Kod ve kategorilerin belirlenmesinde ise içerik analizinden faydalanılmıştır. Öncelikle yabancılar için Türkçe ders kitaplarında yer alan Türk ve Türkiye imajı tespit edilerek sınıflandırılmış,

\footnotetext{
Adres $\mid$ Address

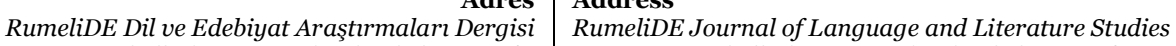
Osmanağa Mahallesi, Mürver Çiçeği Sokak, No:14/8 Osmanağa Mahallesi, Mürver Çiçeği Sokak, No:14/8 Kadıköy - ISTANBUL / TÜRKIYE 34714 Kadıköy - ISTANBUL / TURKEY 34714 e-posta: editor@rumelide.com e-mail: editor@rumelide.com, tel: +90 505 7958124, +90 216773 o 616 phone: +90 505 7958124, +90 2167730616
} 
ardından benzerlik gösterenler kod ve kategorilere ayrılmıştır. Böylelikle ders kitaplarının Türk ve Türkiye imajına ne şekilde ve ne ölçüde yer verdiği tespit edilmiştir.

\section{Geçerlik ve güvenirlik}

Araştırmanın veri analizi sürecinde güvenirliği sağlamak üzere kodlayıcılar arası güvenirlik analizi yapılmıştır. Bu aşamada iki veya daha fazla araştırmacının birbirlerinden bağımsız olarak analiz ettiği nitel bulguların karşılaştırılması yoluna gidilmiştir (Patton, 2014). Bu kapsamda bulgular, iki araştırmacı tarafından bağımsız olarak incelenmiştir. Bu şekilde analiz edilerek ulaşılan sonuçlar, Miles ve Huberman’n (1994) güvenirlik formülüne [görüş birliği / (görüş birliği + görüş ayrıllğı) x 100] başvurularak değerlendirilmiştir. \%96 çıkan uyuşum değeriyle araştırmanın güvenilir olduğu görülmüştür. Uzlaşma göstermeyen verilerin tartışılıp gözden geçirilmesiyle de tüm veriler üzerinde uzlaşma sağlanmıştır.

\section{Bulgular ve yorum}

Yabancı dil olarak Türkçe ders materyallerinde Türk ve Türkiye imajına ilişkin hangi unsurların daha fazla yer aldığına ilişskin bulgular Grafik 1'de sunulmuştur:

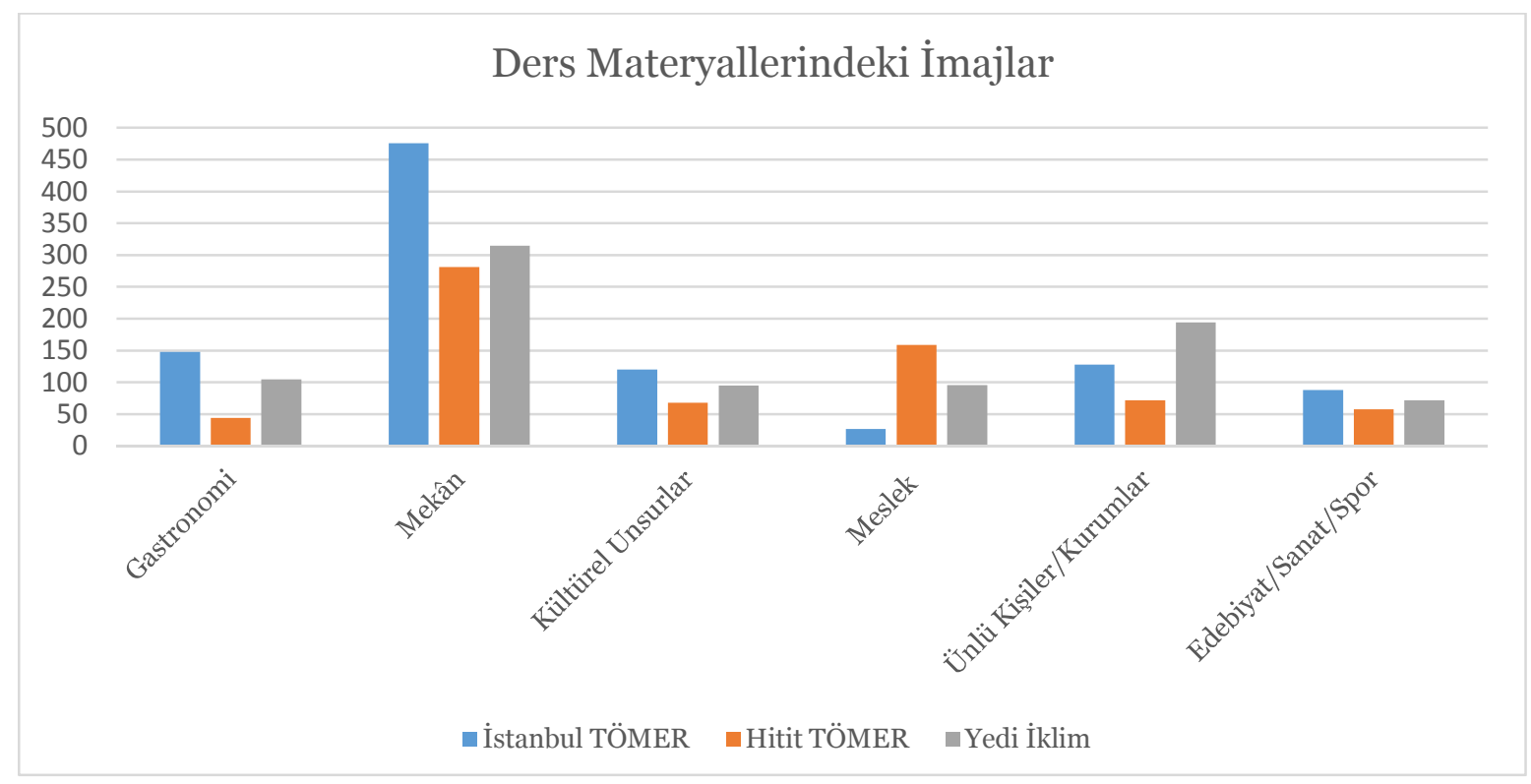

Grafik 1: Yabancılara Türkçe ders materyallerinde kullanılan bütün imajların genel olarak dağılımı

Grafik 1 incelendiğinde bütün öğretim setlerinde mekân ile ilgili unsurlara daha çok yer verildiği tespit edilmiştir. Bunun yanı sıra İstanbul TÖMER öğretim setinde en fazla sırasıyla mekânla ilgili $(\mathrm{f}=476)$, gastronomi ile ilgili ( $\mathrm{f}=148$ ), ünlü kişiler/kurumlarla ilgili ( $\mathrm{f}=128)$, kültürel unsurlarla ilgili ( $\mathrm{f}=120$ ), edebiyat/sanat/sporla ilgili $(\mathrm{f}=88)$ ve mesleklerle ilgili $(\mathrm{f}=27)$ unsurlar kullanılmıştır. Hitit TÖMER öğretim setinde ise surasıyla en fazla mekânla ilgili ( $\mathrm{f}=281$ ), mesleklerle ilgili ( $\mathrm{f}=159$ ), ünlü kişiler/kurumlarla ilgili $(\mathrm{f}=72)$, kültürel unsurlarla ilgili $(\mathrm{f}=68)$, edebiyat/sanat/sporla ilgili $(\mathrm{f}=58$ ) gastronomi ile ilgili $(\mathrm{f}=50)$ unsurlar kullanılmıştır. Yedi İklim öğretim setinde ise en fazla sırasıyla mekânla ilgili ( $\mathrm{f}=315$ ), ünlü kişiler/kurumlarla ilgili ( $\mathrm{f}=194)$, gastronomi ile ilgili ( $\mathrm{f}=105)$, mesleklerle ilgili ( $\mathrm{f}=96)$ kültürel unsurlarla ilgili $(\mathrm{f}=95)$, edebiyat/sanat/sporla ilgili $(\mathrm{f}=72)$ imajlara yer verildiği tespit edilmiştir.

\begin{tabular}{|c|c|}
\hline & \\
\hline alarn $D$ & d Literatur \\
\hline $\mathrm{Mal}$ & Mahallesi, Mürver Çiçeği Sokak, No:14/8 \\
\hline Kadıköy & STANBUL / TURKEY 34714 \\
\hline $\begin{array}{r}\text { e-posta: edito } \\
\text { tel: }+905057958124,+\end{array}$ & $\begin{array}{l}\text { editor@rumelide.com, } \\
\text { +90 505 7958124, +90 } 216773 \text { o } 616\end{array}$ \\
\hline
\end{tabular}


Yabancı dil olarak Türkçe ders materyallerinde tespit edilen Türk ve Türkiye imajına ilişkin unsurlara ilişkin bulgular; Tablo 2, 3, 4, 5, 6 ve 7'de sunulmuştur:

\begin{tabular}{|c|c|c|}
\hline Yayınevi & Düzey & Yabancılara Türkçe Ders Materyallerinde Gastronomi ile ilgili imajlar \\
\hline \multirow{5}{*}{ 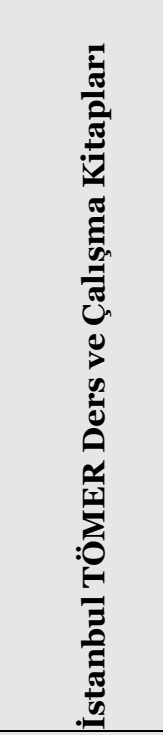 } & A1 & $\begin{array}{l}\text { Kahve (9), çay (3), kebap (3), mercimek çorbası (2), döner, Akdeniz salatası, patlıcan } \\
\text { yemeği }\end{array}$ \\
\hline & A2 & $\begin{array}{l}\text { Kahve (18), çay (11), ayran (5), kebap (6), döner (3), dondurma (3), simit (3), baklava } \\
\text { (3), köfte (3), kadaylf dolması (2), künefe (2), dürüm (2), etli ekmek (2), lahmacun (2), } \\
\text { mercimek çorbası (2), lokum (2), kumpir (2), kokoreç (2), işkembe çorbası, ezogelin } \\
\text { çorbası, yayla çorbasi, içli köfte, yaprak sarma, künefe, sütlaç, kazandibi, baklava, } \\
\text { şalgam suyu, gözleme, pişmaniye, tantuni, çiğ köfte, komposto, sucuk-ekmek }\end{array}$ \\
\hline & B1 & $\begin{array}{l}\text { Döner (3), çay (2), kahve, kebap, balık-ekmek, kumpir, dondurma, dürüm, simit, } \\
\text { imam bayld,, baklava, mantı, kokoreç, hamsi, yoğurt, lokum }\end{array}$ \\
\hline & B2 & Kahve (7), çay (4), mantı, kebap \\
\hline & C1+ & Kahve (3), simit, çay, kebap, hünkarbeğendi \\
\hline \multirow{3}{*}{ 焉 } & $\begin{array}{l}\text { Temel } \\
\text { A1-A2 }\end{array}$ & $\begin{array}{l}\text { Kahve (9), çay (8), soda (3), ayran (2), köfte (2), mercimek çorbası, ezogelin çorbası, } \\
\text { karnıyarık, mantı, cacık, hoşaf, dondurma }\end{array}$ \\
\hline & $\begin{array}{l}\text { Orta } \\
\text { B1 }\end{array}$ & Döner, kahve, aşure, baklava \\
\hline & $\begin{array}{l}\text { Yüksek } \\
\text { B2-C1 }\end{array}$ & Çay (3), kahve (2), hünkarbeğendi, kumpir, testi kebabı, Adana kebabı \\
\hline \multirow{3}{*}{ 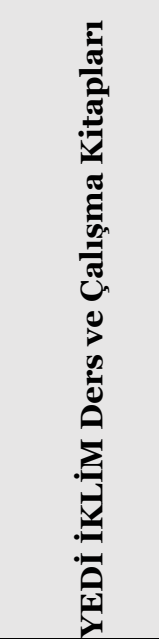 } & $\begin{array}{l}\text { Temel } \\
\text { A1- A2 }\end{array}$ & 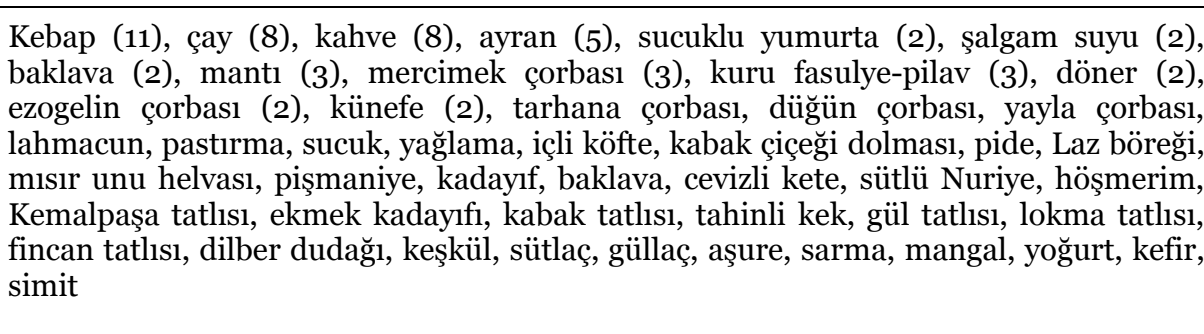 \\
\hline & $\begin{array}{l}\text { Orta } \\
\text { B1-B2 }\end{array}$ & $\begin{array}{l}\text { Çay (3), kahve (3), analı-kızlı çorbası, meyan şerbeti, baklava, badem ezmesi, su } \\
\text { muhallebisi }\end{array}$ \\
\hline & $\begin{array}{l}\text { Yüksek } \\
\text { C1-C2 }\end{array}$ & Kahve (2), çay (2), Osmanlı şerbeti. \\
\hline
\end{tabular}

Tablo 2: Yabancılara Türkçe ders materyallerinde gastronomi (yeme-içme) ile ilgili imajlar

Tablo 2'de Türk imajını yansıtan yiyecek, içecek ve tatlılara ilişkin unsurlara yer verilmiştir. Tabloya bakıldığında genel anlamda tüm ders materyallerinde çay, kahve, döner ve kebap en çok adı geçen Türk yiyecek ve içecekleri olarak karşımıza çıkmaktadır. Bunun yanı sıra özellikle temel düzey (A1 ve A2) ders materyallerinde 'Yiyecek ve İçecekler' ya da 'Yemek Kültürü' adı altında bir temaya yer verildiğinden diğer düzeylere göre yeme-içme ile ilgili daha çok unsurun yer aldı̆̆ dikkat çekmektedir.

\footnotetext{
RumeliDE Dil ve Edebiyat Arașttrmalar Dergisi Osmanağa Mahallesi, Mürver Ciçeği Sokak, No:14/8 Kadıköy - İSTANBUL / TÜRKIYE 34714 e-posta: editor@rumelide.com 
Tüm ders materyalleri incelendiğinde yüksek düzey olarak kabul edilen $\mathrm{C} 1$ ve $\mathrm{C} 2$ düzeylerinde daha az sayıda yeme-içmeyle ilgili unsura yer verildiği de görülmektedir.

Yabancı dil olarak Türkçe ders materyallerinde daha fazla çeşitte gastronomi unsuruna Yedi İklim temel seviye öğretim setinde yer verilmiştir. Kebap ( $f=11)$, çay $(f=8)$, kahve $(f=8)$, ayran $(f=5)$ bu kitapta en sık rastlanan yiyecek ve içeceklerdendir. Bunun yanı sıra kitapta lokma tatlısı, yağlama, içli köfte, kabak çiçeği dolması, Laz böreği, mısır unu helvası, pişmaniye, kadayıf, cevizli kete, sütlü Nuriye, höşmerim, Kemalpaşa tatlısı, ekmek kadayıfı, kabak tatlısı, tahinli kek, gül tatlısı, lokma tatlısı, fincan tatlısı, dilber dudağı, keşkül, sütlaç, güllaç, aşure, sarma gibi Türk mutfağına özgü farklı yiyecek ve içeceklere yer verilmesi dikkat çekicidir. İstanbul TÖMER A2 düzey ders kitabı da fazla çeşitte yiyecek ve içecek ile ilgili unsura yer veren diğer kitaptır. Buna göre kahve ( $f=18)$, çay ( $f=11$ ), ayran $(f=5)$ ve kebap $(f=6)$ kitapta en sık yer verilen yiyecek ve içeceklerdendir.

Gastronomi unsurlarına en az yer veren ders kitabı ise HİTíT orta seviye (B1) ders kitabıdır. Onu İstanbul TÖMER C1 ile Yedi İklim yüksek seviye (C1, C2) kitapları izlemektedir. Seviye ilerledikçe gastronomi unsurlarına daha az yer verildiği de araştırmanın dikkat çekici başka bir sonucudur. Temel düzeyde bir tema olarak gastronomiye yer verilmesi, bu unsurlara temel seviye kitaplarında daha çok yer verilmesini sağlamıştır.

\begin{tabular}{|c|c|c|}
\hline Yayınevi & Düzey & Yabancılara Türkçe Ders Materyallerinde Mekân ile ilgili imajlar \\
\hline \multirow{4}{*}{ 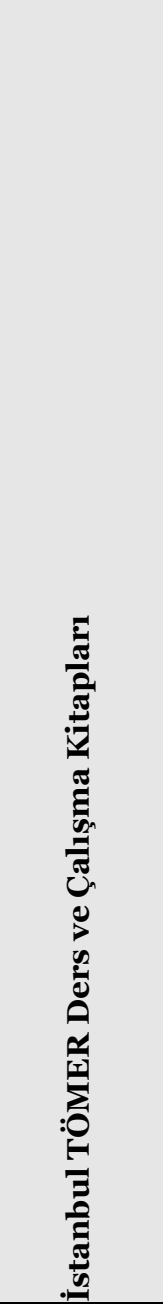 } & A1 & $\begin{array}{l}\text { İstanbul (22), Ankara (16), Antalya (8), İstanbul Üni. (8), Taksim (7), İzmir (7), Beyazıt } \\
\text { (5), Sultanahmet (5), Kadıköy (4), Ayasofya (3), Boğaz (3), Kapalıçarşı (2), Marmara } \\
\text { Üni. (2), Karadeniz (2), Marmara (2), Fatih (2), Şişli, Tophane, Bakırköy, Üsküdar, } \\
\text { Beşiktaş, Ulus, Mecidiyeköy, Çankaya, Kızılay, Levent, Kız Kulesi, Doğu Anadolu, } \\
\text { Güneydoğu Anadolu, Kapadokya, Bursa, Erzurum, Sivas, Yerebatan Sarnıcı, Van Gölü. }\end{array}$ \\
\hline & A2 & $\begin{array}{l}\text { İstanbul (14), Taksim (9), Antalya (8), İzmir (7), Ankara (5), Sultanahmet (4), İstanbul } \\
\text { Üni. (3), Bursa (3), Topkapı Sarayı (3), Kapalıçarşı (3), İstanbul Boğazı (3), Galata (3), } \\
\text { Karadeniz (3), Uludağ (2), Kız Kulesi (2), Bodrum (2), Bolu (2), Efes (2), Üsküdar (2), } \\
\text { Ayasofya, Ortaköy, Eminönü, Beyazıt, Mardin, Adana, Isparta, Rize, Ege Üni., } \\
\text { Çanakkale, Edirne, Kuşadası, Çırağan Sarayı, Akdeniz, Alanya Damlataş Mağarası, } \\
\text { Gaziantep, Uludağ, Nişantaşı, Kapadokya, Büyükada, Bozcaada, Kuşadası, Cunda, } \\
\text { Meryem Ana Kilisesi, Aya Yogi Kilisesi, Sabancı Müzesi, Pera Müzesi, Rahmi Koç } \\
\text { Müzesi, oyuncak müzesi, İstanbul Modern Sanat Müzesi, Mısır Çarşısı, Yeni Cami, } \\
\text { Tahtakale, Kuru Kahveci Mehmet Efendi, Sahaflar Çarşısı, Sirkeci, Heybeliada, Kadıköy, } \\
\text { Ağva, Rumelihisarı }\end{array}$ \\
\hline & B1 & $\begin{array}{l}\text { İstanbul (23), Taksim (8), Ankara (4), İstanbul Üni. (3), Kadıköy (3), Antalya (2), } \\
\text { Galatasaray Lisesi (2), Beşiktaş, Şile, Kilyos, İstanbul Boğazı, Fethiye, Acıbadem, } \\
\text { Sarıer, Maltepe, Uludağ, Malatya, Topkapı, Sarıer, Sultanahmet, Bodrum, Eminönü, } \\
\text { Üsküdar, Fatih, Beylikdüzü, Levent, Tophane, Bilkent Üni., Firat nehri, İzmir, ODTü, } \\
\text { Bakırköy, Alman Lisesi, İstanbul Robert Koleji, Saint Benoit Lisesi, Belgrad Orman,, } \\
\text { Ortaköy, Anadolu Hisarı, Adalar, Kuşadası. }\end{array}$ \\
\hline & B2 & $\begin{array}{l}\text { İstanbul (8), Antalya (5), İzmir (5), Ankara (5), Taksim (3), Efes (3), Meryemana Evi (3), } \\
\text { Sultanahmet (3), Beyoğlu (2), Pamukkale (2), Bursa (2), İstanbul Üni. (2), Kapadokya } \\
\text { (2), Konya (2), Yalova, Marmaris, Kapalıçarşı, Bodrum, Güneydoğu Anadolu, İstiklâl } \\
\text { Caddesi, Karaköy, Topkapı Sarayı, Büyük Kanyon, Nemrut, Adıyaman, Çemberlitaş } \\
\text { Hamamı, Ege Bölgesi, KKTC, Beşparmak Dağları, İstanbul Boğazı, Fatih-Harbiye, } \\
\text { Moda-Kadıköy, Sirkeci Garı, İstanbul Oyuncak Müzesi, Göztepe, Edirne, II. Beyazıt } \\
\text { Külliyesi, Edirne Şifahanesi, Peri Bacaları, Üsküdar, Trabzon-Uzungöl, Sümela } \\
\text { Manastırı, Sivas }\end{array}$ \\
\hline & $\begin{array}{r}\text { Rum } \\
\text { Osman }\end{array}$ & \begin{tabular}{r|l} 
Adres & Address \\
Pil ve Edebiyat Arassttrmalart Dergisi & RumeliDE Journal of Language and Literature Studies \\
hallesi, Mürver Ciçeği Sokak, No:14/8 & Osmanağa Mahallesi, Mürver Ciçeği Sokak, No:14/8 \\
diköy - İSTANBUL / TÜRKIYE 34714 & Kadköy - ISTANBUL / TURKEY 34714 \\
e-posta: editor@rumelide.com & e-mail: editor@ rumelide.com, \\
phone: +90 505 7958124, +90 216 773 o 616
\end{tabular} \\
\hline
\end{tabular}




\begin{tabular}{|c|c|c|}
\hline & $\mathrm{C1}+$ & $\begin{array}{l}\text { İstanbul (12), Çanakkale (4), Trabzon (3), İstanbul Üni. (3), Taksim (3), Ankara (3), } \\
\text { Ayasofya (2), Bakırköy (2), Beyazıt Meydanı (2), Gaziantep (2), Bursa (2), İzmir Saat } \\
\text { Kulesi, Dolmabahçe Saat Kulesi, Ankara Saat Kulesi, Gökçeada, Kanlıca, Moda, Adalar, } \\
\text { Mevlana Türbesi, Fatih, Kayseri, Abant, Yenikapı, Ege, Samatya, Çengelköy, Hacettepe } \\
\text { Üni, İstanbul Erkek Lisesi, Ankara Devlet Tiyatrosu, İstanbul Devlet Tiyatrosu, İstanbul } \\
\text { Şehir Tiyatrosu, Düzce, Marmara, Akşehir, Bilkent Üni., Etnografya Müzesi, Fatih, Şişli, } \\
\text { Çamlıca, Cağaloğlu, Galata Kulesi, Denizli Çivril-Sarayköy, Sivas, Sultanahmet, Yeni } \\
\text { Cami, Beşiktaş, Erzurum, Erzincan, İTÜ, Maçka, Darülfünun, Nizamiye Medresesi, } \\
\text { Elazığ, İstanbul Modern Müzesi, Mimar Sinan Üni,, Çankırı, Ergani }\end{array}$ \\
\hline \multirow{3}{*}{ : } & $\begin{array}{l}\text { Temel } \\
\text { A1-A2 }\end{array}$ & $\begin{array}{l}\text { Ankara (23), İstanbul (15), Antalya (11), İzmir (7), Karadeniz (6), Bodrum (4), Akdeniz } \\
\text { (3), Ankara Üni. (3), Boğaziçi Üni. (3), Erzurum (3), Ege (2), Bursa (2), Marmara (2), } \\
\text { Kızlay (2), Çankaya (2), Çırağan Sarayı (2), Topkapı Sarayı (2), Kapalıçarşı (2), Trabzon } \\
\text { (2), Güvenpark, Artvin, Rize, Samsun, Bolu, Boğaz Köprüsü, Fatih Sultan Mehmet } \\
\text { Köprüsü, Ortaköy, Ayasofya Müzesi, Kız Kulesi, Dolmabahçe Sarayı, Adalar, Çiçek } \\
\text { Pasajı, Haydarpaşa Tren Garı, İstiklâl Caddesi, Marmara Bölgesi, Ankara Devlet } \\
\text { Tiyatrosu, Alanya, Maltepe, Anadolu Üni., Konya, Van Akdamar Adası, Kapadokya, } \\
\text { Göreme, Peri Bacaları, Avanos, Ürgüp, Balıesir, Edremit, Altınoluk, Bandırma, Kuş } \\
\text { Cenneti, Akçay, Gönen, İstanbul Üni., Kaçkar dağları, Alaçatı, Muğla, Bodrum Kalesi, } \\
\text { Fethiye, Ölüdeniz, Efes Antik Tiyatro, Uludağ, Mersin, Güneydoğu Anadolu, Beşiktaş, } \\
\text { Sualtı Arkeoloji Müzesi (Bodrum), Kızılay Meydanı, Zonguldak, Adana, Van Gölü, } \\
\text { Anadolu Medeniyetler Müzesi, Bolu Aladağ, Çanakkale Boğazı, Palandöken, Çeşme, } \\
\text { ODTü }\end{array}$ \\
\hline & $\begin{array}{l}\text { Orta } \\
\text { B1 }\end{array}$ & $\begin{array}{l}\text { İstanbul (18), Antalya (11), Ankara (7), İzmir (5), Büyükada (3), Taksim (3), Çeşme (2), } \\
\text { Topkapı Sarayı (2), Konyaaltı, Lara, Ayasofya, Levent, Ankara Üni., Çankaya, Anadolu } \\
\text { Üni., Koç Üni., Ege Üni., Van, Konya, Beşiktaş, Ortaköy, Elazı̆̆, İTÜ, Erzurum, Akdeniz, } \\
\text { ODTÜ, Beypazarı, Boğaziçi Üni., Anıtkabir, Manisa, Kızılırmak, Erdemli, Sakarya, } \\
\text { Sapanca, Sultanahmet Cami, Nemrut Dağı, Derinkuyu yeraltı şehri, Ankara Devlet } \\
\text { Konservatuarı, Bodrum, Kütahya, Marmaris, Etlik, İstanbul Boğazı, Kızllay, Ege, } \\
\text { Beyoğlu, Süleymaniye Camii, Beyoğlu, Şişli, Belkıs Zeugma Antik Kenti (Gaziantep- } \\
\text { Nizip) }\end{array}$ \\
\hline & $\begin{array}{l}\text { Yüksek } \\
\text { B2-C1 }\end{array}$ & $\begin{array}{l}\text { İstanbul (8), Ankara (3), İzmir (3), Çankaya (2), Antalya (2), Uludă̆, İTÜ, Cunda Adası, } \\
\text { Ankara Etnografya Müzesi, Rumeli Hisarı, Selimiye Camii, Bolu-Mengen, Asos } \\
\text { (Çanakkale-Behramkale Köyü), Beylikdüzü, Kapadokya, Karadeniz, Ilgaz Dağı, ODTÜ, } \\
\text { Bodrum, Dolmabahçe Sarayı, İstanbul-Boğaziçi, Kabataş, Beşiktaş }\end{array}$ \\
\hline \multirow{2}{*}{ : } & $\begin{array}{l}\text { Temel } \\
\text { A1- A2 }\end{array}$ & $\begin{array}{l}\text { Ankara (21), İstanbul (20), Antalya (10), İzmir (6), Kızılay (6), Kayseri (5), Konya (4), } \\
\text { Safranbolu-Amasra (3), Gazi Üni. (2), Bursa (2), Anıtkabir (2), Adana (2), Karadeniz (2), } \\
\text { Amasya (2), Marmara (2), Ege (2), Akdeniz (2), Sümela Manastırı (2), ODTÜ (2), Ağrı } \\
\text { Dağı (2), Erzurum (2), Erzincan (2), Eskişehir (2), Topkapı Sarayı (2), İstanbul Boğazı, } \\
\text { Ankara Üni., Bilkent Üni., Marmara Üni., Mimar Sinan Üni., Kızlcahamam, Tuz Gölü, } \\
\text { Van Gölü, Mersin, Tekirdağ, İstanbul Üni., Çankaya, Ulus, Tandoğan, Ulucanlar, } \\
\text { Güvenpark, Hacı Bayram Veli Türbesi (Ankara), Süleymaniye Camii, Sultanahmet, } \\
\text { Eminönü, Kızılırmak, Gaziantep, Maraş, Diyarbakır, Haydarpaşa Tren Garı, Taksim, } \\
\text { Eminönü, Ağrı, Büyükada, Kapadokya, Bartın, Gaziantep, Bolu-Gerede, Doğu } \\
\text { Karadeniz, Furtına Vadisi, Uzungöl, Ayder, Fethiye, Trabzon, Atatürk Üni., Nevşehir, } \\
\text { Erciyes Dağı, Üsküdar, Ürgüp, Eskişehir, Çanakkale, Anzak Koyu, Conkbayırı, Truva } \\
\text { Antik Kenti, Fethiye/Ölüdeniz, Nemrut Dağı, Kapadokya, Şile, Ayasofya Müzesi, } \\
\text { Topkapı Sarayı, Fatih, Trabzon, Rize, Florya, Selimiye Cami, Nevşehir Kurşunlu Camii, } \\
\text { Kayseri Şeyh İbrahim Tennurî Çeşmesi, Kocaeli, Kayseri, Ordu, Bitlis, Eskişehir, Artvin, } \\
\text { Çoruh, Yusufeli, Bayburt, İç Anadolu, Doğu Anadolu, Güneydoğu Anadolu, Anadolu } \\
\text { Medeniyetleri Müzesi, Cunda, Altınoluk, Nemrut Heykeli, Alanya Kalesi, Truva Atı, } \\
\text { Ayasofya Müzesi, Palandöken }\end{array}$ \\
\hline & $\begin{array}{l}\text { Orta } \\
\text { B1-B2 }\end{array}$ & $\begin{array}{l}\text { İstanbul (14), Ankara (6), Edirne (3), İstanbul Üni. (3), İzmir (2), Antalya, Maraş, } \\
\text { Ayasofya, Balıkesir, Marmaris, Galata Kulesi, Çengelköy, Kız Kulesi, Beyazıt, Ayasofya, } \\
\text { Eminönü, Eyüp, Adalar, Sivas, Marmara Üni., Kırşehir, Sirkeci, İTÜ, Ulus, Kırgızistan }\end{array}$ \\
\hline \multicolumn{3}{|c|}{$\begin{array}{r}\text { Adres } \\
\text { RumeliDE Dil ve Edebiyat Araştrrmaları Dergisi } \\
\text { Osmanağa Mahallesi, Mürver Ciç̧egi Sokak, No:14/8 } \\
\text { Kadlköy - İTANBUL / TÜRKiYE } 34714 \\
\text { e-posta: editor@rumelidecom } \\
\text { tel: +90 } 5057958124,+90216773 \text { o } 616\end{array}$} \\
\hline
\end{tabular}




\begin{tabular}{l|l|l}
\hline & $\begin{array}{l}\text { Manas Üni, Hacettepe Üni., Ankara Üni., Muğla, Kastamonu, Erzurum, Konya, Çankırı, } \\
\text { Krrıkale, Adlyaman, Kayseri, Şarkışla, Kırıkale, Karadeniz, Bülent Ecevit Üni., } \\
\text { Süleymaniye Camii, Selimiye Camii, Şehzadebaşı Camii }\end{array}$ \\
\cline { 2 - 3 } & $\begin{array}{l}\text { Yüksek } \\
\text { C1-C2 }\end{array}$ & $\begin{array}{l}\text { İstanbul (10), İzmir (6), Ankara (5), Bursa (4), Eskişehir (2), İstanbul Boğazı (2), } \\
\text { Beyoğlu, Sinop, Adana, Balıesir, Bayburt, Antakya, Adana, Kars, Artvin, Çorum- } \\
\text { Hattuşaş, Ankara Üni, İstanbul Üni., ODTü, İTü, Karadeniz, Topkapi Sarayı, Bursa Ulu } \\
\text { Camii, Mevlâna Müzesi, Antalya, Erzurum, Doğu Anadolu, Şavşat, Çorum, Malatya, } \\
\text { Erzincan, Sivas, Konya, Karaman, Kızllırmak, Yeşilırmak, Fırat, Dicle }\end{array}$ \\
\hline
\end{tabular}

Tablo 3: Yabancılara Türkçe ders materyallerinde mekân ile ilgili imajlar

Tablo 3’te yabancı dil olarak Türkçe ders materyallerinde mekân ile ilgili unsurlara bakıldığında İstanbul, Ankara, İzmir gibi büyük şehirlere daha fazla yer verildiği dikkat çekmektedir. Bununla birlikte İstanbul'un semtlerine de ders kitaplarında mekân olarak sıkça yer verilmiştir. Ders kitaplarında genel olarak tarihî, popüler ve turistik mekânlara daha çok yer verildiği görülmektedir.

İstanbul TÖMER öğretim setinde diğer kitaplara göre daha fazla sayıda ve çeşitte mekâna yer verildiği dikkat çekmektedir. Bu öğretim setinde İstanbul, semtleriyle birlikte en çok yer verilen mekânlardan olmuştur. İstanbul'u Ankara, Antalya ve İzmir takip etmektedir. Kitapta büyük şehirler dışında Kapadokya, Van Gölü, Yerebatan Sarnıcı, Kapalıçarşı, Sultanahmet, İstanbul Boğazı, Mevlâna Türbesi, Anadolu Hisarı, Topkapı Sarayı, İstiklâl Caddesi, Peri Bacaları, Kız Kulesi, Efes, Aya Yogi Kilisesi gibi tarihî ve turistik mekânlara da yer verilmiştir. Kitaplarda bu mekânların yanı sıra Antalya, İzmir, Ağva, Kuşadası, Cunda, Uludağ, Bodrum, Adalar, Pamukkale, Fethiye, Yalova, Marmaris gibi popüler tatil beldelerine de geniş oranda yer verilmiştir.

Hitit öğretim seti ise diğer yayınevlerine göre daha az sayıda mekân unsuruna yer vermiştir. İstanbul ve Ankara, bu öğretim setinde en çok adı geçen iki şehir olarak karşımıza çıkmaktadır. Bunun yanı sıra A1 ve A2 düzeyi kitaplarda diğer düzeylere göre daha fazla sayıda mekâna yer verildiği dikkat çekmektedir. Buna göre temel düzey ders kitaplarında (A1 ve $\mathrm{A2}$ ), Ankara ( $\mathrm{f}=23)$, İstanbul $(\mathrm{f}=15)$ ve Antalya ( $\mathrm{f}=11)$; orta düzey ders kitaplarında (B1) İstanbul $(\mathrm{f}=18)$, Antalya $(\mathrm{f}=11)$ ve Ankara $(\mathrm{f}=7)$; yüksek seviye ders kitaplarında (B2 ve $\mathrm{C} 1$ ); İstanbul $(\mathrm{f}=8)$, Ankara ( $\mathrm{f}=3$ ) ve İzmir ( $\mathrm{f}=3$ ) en çok adı geçen şehirler olarak karşımıza çıkmaktadır.

Yedi İklim öğretim setinde ise temel seviyede daha fazla sayıda mekâna yer verildiği tespit edilmiştir. Buna göre temel seviyede (A1 ve A2) en çok İstanbul ( $f=21)$, Ankara ( $f=20)$ ve Antalya $(f=10)$; orta seviyede İstanbul ( $\mathrm{f}=14$ ), Ankara ( $\mathrm{f}=6$ ) ve Edirne ( $\mathrm{f}=3$ ); yüksek seviyede İstanbul ( $\mathrm{f}=10$ ), İzmir $(\mathrm{f}=6)$ ve Ankara $(\mathrm{f}=5)$ şehirlerine sıkça yer verildiği tespit edilmiştir. Görüldüğü gibi özellikle İstanbul ve Ankara, Yedi İklim öğretim setinde yer alan kitaplarda en çok kullanılan mekânlar olarak dikkat çekmektedir. Bunun yanı sıra temel seviye kitaplarda İzmir $(\mathrm{f}=6)$, Kuzılay $(\mathrm{f}=6)$, Kayseri $(\mathrm{f}=5)$, Konya $(\mathrm{f}=4)$, Safranbolu-Amasra ( $\mathrm{f}=3$ ), Gazi Üniversitesi $(\mathrm{f}=2)$, Bursa $(\mathrm{f}=2)$, Antkabir $(\mathrm{f}=2)$, Adana $(\mathrm{f}=2)$, Karadeniz ( $f=2)$, Amasya $(f=2)$, Marmara $(f=2)$, Ege $(f=2)$, Akdeniz $(f=2)$, Sümela Manastırı $(f=2)$, ODTÜ ( $f=2)$, A $\breve{g r ı ~ D a g ̆ ı ~}(f=2)$, Erzurum ( $f=2)$, Erzincan ( $f=2)$, Eskişehir $(f=2)$, Topkapı Sarayı $(f=2)$ gibi mekânlar da yer almaktadır. Orta seviye kitaplarda ise İstanbul Üniversitesi $(f=3)$, Yunus Emre Enstitüsü ( $\mathrm{f}=3$ ), İzmir ( $\mathrm{f}=2$ ) diğer bahsedilen mekânlar olarak karşımıza çıkmaktadır. Yüksek seviye kitaplarda ise Bursa $(\mathrm{f}=4)$, Eskişehir $(\mathrm{f}=2)$, İstanbul Boğazı $(\mathrm{f}=2)$ diğer en çok adı geçen mekânlardandır. 


\begin{tabular}{|c|c|c|c|}
\hline Yayınevi & Düzey & \multicolumn{2}{|c|}{$\begin{array}{l}\text { Yabancilara Türkçe Ders Materyallerinde Kültürel Unsurlar (Dinî ve Millî) } \\
\text { ile ilgili imajlar }\end{array}$} \\
\hline & A1 & \multicolumn{2}{|c|}{$\begin{array}{l}\text { Geniş aile (7), millî bayramlar (4) -23 Nisan, } 29 \text { Ekim, } 19 \text { Mayıs, } 30 \text { Ağustos-, dinî } \\
\text { bayramlar (3) -Ramazan Bayramı, Kurban Bayramı, bayramlaşmak-, akraba ziyareti } \\
\text { yapmak, siyaset ve din hakkında konuşmak, millî marş, Hıdırellez, kilim, cami }\end{array}$} \\
\hline & A2 & \multicolumn{2}{|c|}{$\begin{array}{l}\text { Futbol oynamak/izlemek (5), piknik yapmak (4), akraba ziyareti (3), halk oyunları } \\
\text { oynamak (3), huzurevi ziyareti (2), çocuk yuvası ziyareti, komşu ziyareti, altın günü } \\
\text { yapmak, kı isteme ritüeli, fal bakmak, batıl inançlar, fayton turu, tavla oynamak, rüya } \\
\text { tabiri, Boğaz turu yapmak, balı tutmak, klasik Türk müziği dinlemek, görücü usüü } \\
\text { evlilik }\end{array}$} \\
\hline : & B1 & \multicolumn{2}{|c|}{$\begin{array}{l}\text { Misafirperverlik (4), komşuluk ilişkileri (4), bayram ziyareti (2), ayakkabı çıarma âdeti } \\
\text { (2), geniş aile (2), selamlaşma, özel hayatla ilgili soru sorma, futbol fanatiği olma, } \\
\text { hamam kültürü, ikram, bayramlaşma, akraba ziyareti, bayram harçlı̆̆ı, yardımlaşma, } \\
\text { altın günü, düğün ve cenaze âdetleri, görücü usulü evlilik, batıl inançlar, akrabalık } \\
\text { ilişkileri, nalın, peştamal, bohça, at nalı, nazar boncuğu, fil dişi, ezan, namaz, } 40 \\
\text { sayısının uğuru, cami }\end{array}$} \\
\hline $\begin{array}{l}\frac{5}{0} \\
\frac{0}{2} \\
\frac{1}{2}\end{array}$ & B2 & \multicolumn{2}{|c|}{$\begin{array}{l}\text { Cami (3), Osmanlı İmparatorluğu (3), askere gitmek, yardımlaşmak, hamam kültürü, } \\
\text { misafirperverlik, Hz. Eyüp, Hz. İsa, millî bayramlar -29 Ekim-, Nevruz, } 12 \text { Hayvanlı } \\
\text { Türk takvimi, tavla oynamak, davul }\end{array}$} \\
\hline :゚ & $\mathrm{C1}+$ & \multicolumn{2}{|c|}{$\begin{array}{l}\text { Misafirperverlik (2), Osmanlı İmparatorluğu (2), akraba ziyareti, memleket ziyareti, } \\
\text { tuzlu kahve pişirme âdeti, askere gitme, ev hediyesi almak, el öpme, Ramazan ayı, millî } \\
\text { bayramlar -23 Nisan-, Hıdırellez, peştamal, } 12 \text { Hayvanlı Türk Takvimi }\end{array}$} \\
\hline & $\begin{array}{l}\text { Temel } \\
\text { A1-A2 }\end{array}$ & \multicolumn{2}{|c|}{$\begin{array}{l}\text { Piknik yapmak (2), akraba ziyareti, İstanbul renkli gece hayatı, yılbaşı kutlamaları, } \\
\text { yardımseverlik, geleneksel çocuk oyunları (saklambaç, beş taş, körebe oynamak), geniş } \\
\text { aile, cami }\end{array}$} \\
\hline 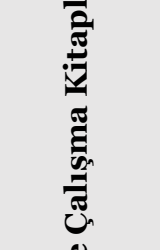 & $\begin{array}{l}\text { Orta } \\
\text { B1 }\end{array}$ & \multicolumn{2}{|c|}{$\begin{array}{l}\text { Millî bayramlar/günler (5) -29 Ekim, } 23 \text { Nisan, } 9 \text { Eylül-, akraba ziyareti (4), dinî } \\
\text { bayramlar/günler (4) -arife günü, Hıdırellez, Muharrem ayı-, bayram harçlığı toplamak } \\
\text { (3), bayram şekeri (2), el öpme (2), batıl inanışlar (2), bayramlı (2), bayram tebrikleri } \\
\text { (2), sarılıp öpüşmek, piknik yapmak, çeyiz hazırlama, geniş aile, Osmanlı } \\
\text { İmparatorluğu, Anıtkabir ziyareti, Ramazan davulcusu, kolonya ikramı, Hz. Hızır, Hz. } \\
\text { İlyas, bayram baklavası, bayram ziyaretleri, kasket, şalvar, yemeni, oyalı yazma, at nalı }\end{array}$} \\
\hline 党 & $\begin{array}{l}\text { Yüksek } \\
\text { B2-C1 }\end{array}$ & \multicolumn{2}{|c|}{$\begin{array}{l}\text { Misafirperverlik (3) -misafir odası, misafir ağırlamak, misafir sofrası-, askerlik (2), cami } \\
\text { (2), komşuluk ilişkileri, bayram ziyaretleri, el öpme, millì bayramlar -29 Ekim-, saz, } \\
\text { cumbalı evler, sofa, yüklük, Bodrum ev mimarisi }\end{array}$} \\
\hline & $\begin{array}{l}\text { Temel } \\
\text { A1- A2 }\end{array}$ & \multicolumn{2}{|c|}{$\begin{array}{l}\text { Namaz kılmak (4), cami (3), el öpmek (3), bayramlaşmak (3), Türk hamamı ritüeli (3) - } \\
\text { gelin hamamı, damat hamamı, hamamda kız beğenme-, dinî bayramlar/günler (2) - } \\
\text { Ramazan Bayramı Muharrem ayı-, Ramazan orucu, piknik yapmak, Ada'da fayton ile } \\
\text { gezmek, bayramlaşmak, bayram ziyareti, bayramda tatlı ikram etmek, bayram harçlığ } 1 \\
\text { vermek, komşuya ikram, boş gelen tabağı doldurma, akrabalı ilişkileri, } \\
\text { misafirperverlik, kilim, çini sanatı, kuş evleri }\end{array}$} \\
\hline 光言 & $\begin{array}{l}\text { Orta } \\
\text { B1-B2 }\end{array}$ & \multicolumn{2}{|c|}{$\begin{array}{l}\text { Misafirperverlik (13) -misafir odası, misafir ağırlama, kolonya ve şeker ikramı-, kız } \\
\text { isteme ritüeli (11) -düğün merasimi, yüz görümlüğü, davul-zurna, gelin çlkarma, } \\
\text { beşibiryerde, kına gecesi, tuzlu kahve ikram etmek, bir yastıkta kocamak, küstüm } \\
\text { yastığı, takı merasimi-, dinî bayramlar/günler (8) -Ramazan Bayramı, bayramlaşmak, } \\
\text { arife günü, bayram harçlığı almak, ezan, bayram namazı, bayram şekeri -, ikram (3), saz }\end{array}$} \\
\hline \multicolumn{3}{|c|}{$\begin{array}{r}\text { Adres } \\
\text { RumeliDE Dil ve Edebiyat Araşttrmaları Dergisi } \\
\text { Osmanağa Mahallesi, Mürver Ciçeği Sokak, No:14/8 } \\
\text { Kadıöy - İSTANBUL / TÜRKIYE 34714 } \\
\text { e-posta: editor@rumelide.com } \\
\text { tel: }+90 \text { 505 7958124, +90 216 773 o } 616\end{array}$} & $\begin{array}{l}\text { Address } \\
\text { RumeliDE Journal of Language and Literature Studies } \\
\text { Osmanağa Mahallesi, Mürver Çiceği Sokak, No:14/8 } \\
\text { Kadıköy - ISTANBUL / TURKEY } 34714 \\
\text { e-mail: editor@ rumelide.com, } \\
\text { phone: +90 505 7958124, +90 } 216773 \text { o } 616\end{array}$ \\
\hline
\end{tabular}




\begin{tabular}{l|l|l}
\hline & $\begin{array}{l}\text { (3), bayramlaşmak (2), el öpmek (2), komşuluk ilişkileri, imece, ad verme geleneği, } \\
\text { Karadeniz kadınlarının çalışkanlığı, fal bakmak, köy odaları, Nevruz Bayramı, Hıdırellez, } \\
\text { selamlaşmak, , ney, fes, davul }\end{array}$ \\
\cline { 2 - 3 } & $\begin{array}{l}\text { Yüksek } \\
\text { C1-C2 }\end{array}$ & $\begin{array}{l}\text { Geleneksel ev mimarisi (4) -Antakya, Safranbolu, Mardin, Kapadokya evleri-, batıl } \\
\text { inançlar, Türklerde sayılar (7, 9, 12, 13, 40 sayıları), baş örtüsü, sarık, kaftan }\end{array}$ \\
\hline
\end{tabular}

Tablo 4: Yabancılara Türkçe ders materyallerinde kültürel unsur (dinî ve millî) ile ilgili imajlar

Tablo 4’e göre yabancı dil olarak Türkçe ders materyallerinde kültürel unsurlarla ilgili imajlara genel olarak bakıldığında misafirperverlik, millı̂ bayramlar/günler ve dinî bayramlar/günler ile ilgili unsurların diğerlerine nazaran çokça yer aldığı görülmektedir.

İstanbul TÖMER öğretim setine göre A1 düzeyinde en çok geniş aile $(\mathrm{f}=7)$, A2 düzeyinde en çok futbol oynamak/izlemek ( $f=5$ ), B1 ve $\mathrm{C}$ 1 düzeylerinde en çok misafirperverlik ( $\mathrm{f}=3, \mathrm{f}=2$ ), B2 düzeyinde en çok cami (f=3) ile ilgili kültürel imajlar kullanılmıştır. Bunların yanı sıra A1 düzeyindeki ders kitaplarında millî ve dinî bayramlar dışında siyaset ve din hakkında konuşmak Türk insanına özel bir durum olarak yansıtılmıştır. A2 düzeyindeki kitaplarda ise piknik yapmak ( $\mathrm{f}=4)$, akraba ziyareti yapmak $(\mathrm{f}=3)$, halk oyunları oynamak ( $\mathrm{f}=3$ ), huzurevi ve çocuk yuvası ziyareti yapmak gibi aktiviteler $(\mathrm{f}=3$ ) Türk insanına has etkinlikler olarak anlatılmıştır. Ayrıca fal bakmak, batıl inançlar ve görücü usulü evlilik gibi olumsuz kültürel ögeler de kitapta yer almaktadır. Nalın, peştamal, bohça, at nalı, nazar boncuğu, fil dişi, davul gibi nesneler ise kültürel birer öge/nesne olarak ders kitaplarında kendine yer bulmuştur.

Hitit öğretim setine bakıldığında ise temel seviyede piknik yapmak ( $\mathrm{f}=2)$, orta seviyede millî bayramlar/günler $(\mathrm{f}=5)$ ve yüksek seviyede misafirperverlik $(\mathrm{f}=3)$ ile ilgili imajlara çokça yer verildiği dikkat çekmektedir. Bunun yanı sıra aynı öğretim setinde yer alan orta seviye materyallerde akraba ziyareti (4), dinî bayramlar/günler (4) -arife günü, Hıdırellez, Muharrem ayı-, bayram harçlı̆̆ı toplamak (3), bayram şekeri (2), el öpme (2), batıl inanışlar (2), bayramlık (2), bayram tebrikleri (2) gibi kültürel unsurlara yer verildiği dikkat çekmektedir. Ayrıca temel düzeyde geleneksel çocuk oyunlarına da (saklambaç, beş taş, körebe) kültürel bir unsur olarak yer verilmesi dikkat çekicidir. Bunun yanı sıra temel düzey kitaplarında İstanbul'un renkli gece hayatı ve yılbaşı kutlamalarının geleneksel bir unsur olarak yansıtıldığı görülmektedir. Bunlar dışında kasket, şalvar, yemeni, oyalı yazma, at nalı, saz gibi nesneler de kültürel ögeler olarak ders kitaplarında kendine yer bulmuştur.

Yedi İklim öğretim setinde ise misafirperverlik ( $\mathrm{f}=13$ ), namaz kılmak ( $\mathrm{f}=4$ ) ve geleneksel ev mimarisi $(\mathrm{f}=4)$ ile ilgili kültürel imajlar çokça yer almıştır. Ayrıca orta düzey kitaplarda Türk âdetlerinden olan kız isteme ritüelinin de düğün merasimi, yüz görümlüğü, davul-zurna, gelin çıkarma, beşibiryerde, kına gecesi, tuzlu kahve ikramı, bir yastıkta kocamak, küstüm yastığı, takı merasimi gibi unsurlar ve deyimlerle ele alındığı dikkat çekmektedir. Bunun yanı sıra Türk kültüründe var olan akrabaya, misafire ve komşuya ikramda bulunmak da orta düzey ders kitaplarında yer verilen kültürel imajlardandır ( $\mathrm{f}=3$ ). Yine bu düzeyde komşuluk ilişkileri, imece, ad verme geleneği, Karadeniz kadınlarının çalışkanlı̆̆ı, fal bakmak, köy odaları, Nevruz Bayramı, Hıdırellez, selamlaşmak, bayram harçlı̆̆ı almak, ezan, bayram namazı, bayram şekeri, gibi kültürel unsurlar, Türk imajını yansıtmada kullanılan ögelerdendir. Ayrıca dinî bayramlar/günler ile ilgili imajlar da Ramazan Bayramı, bayramlaşmak, arife günü, bayram harçlı̆̆ almak, ezan, bayram namazı, bayram şekeri gibi ögelerle kendine yer bulmuştur. Bunlar dışında ney, davul, başörtüsü, fes, sarık, kaftan ve kilim gibi ögeler de kültürün bir parçası olarak ders kitaplarında kendine yer bulmuştur. İncelenen ders kitaplarında fes,

\footnotetext{
RumeliDE Dil ve Edebiyat Araștırmaları Dergisi Osmanağa Mahallesi, Mürver Ciçeği Sokak, No:14/8 Kadıköy - İSTANBUL / TÜRKIYE 34714 e-posta: editor@rumelide.com tel: +90 $5057958124,+902167730616$ 
sarık, kaftan gibi Türk kültürüne ait geleneksel kıyafetlerin günümüzde kullanılmadığı ve nostalji biçiminde kabul gördüğü de vurgulanmıştır.

\begin{tabular}{|c|c|c|}
\hline Yayınevi & Düzey & Yabancılara Türkçe Ders Materyallerinde Meslekler ile ilgili imajlar \\
\hline \multirow{5}{*}{ 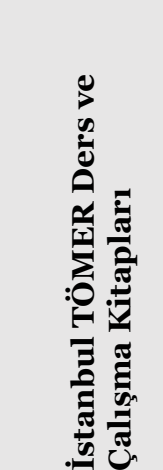 } & A1 & Ev hanımı (4), öğretmen (3), doktor (3) \\
\hline & A2 & Öğretmen, doktor \\
\hline & B1 & Ev hanımı (2), Ramazan davulcusu \\
\hline & B2 & Öğretmen, banka memuru, eskici, davulcu, zurnacı \\
\hline & C1+ & Ev hanımı, simitçi, kebapçı, kasap, sigortacı, işçi, arzuhâlci \\
\hline \multirow{3}{*}{ 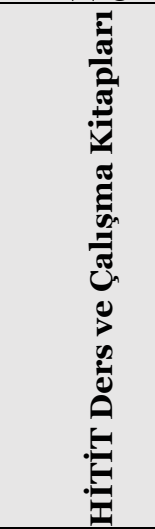 } & $\begin{array}{l}\text { Temel } \\
\text { A1-A2 }\end{array}$ & $\begin{array}{l}\text { Öğretmen (8), doktor (5), müdür (3), avukat (2), mühendis (2), kadın taksici, pilot, } \\
\text { postacı, garson, dağcı, fotoğrafçı, hemşire, mimar, bankacı, moda tasarımcısı, garson, } \\
\text { erkek dadı, hemşire, mimar, sekreter, gazeteci }\end{array}$ \\
\hline & $\begin{array}{l}\text { Orta } \\
\text { B1 }\end{array}$ & $\begin{array}{l}\text { Müdür (14), doktor (13), öğretmen (11), avukat (7), taksici (3), terzi (2), mimar (2), ev } \\
\text { hanımı, yönetici asistanı, gazeteci, fotoğrafçı, DJ, futbolcu, polis, boyacı, hemşire, } \\
\text { seyyar satıcı, garson, dönerci, tezgâhtar, kasiyer, tasarımcı }\end{array}$ \\
\hline & $\begin{array}{l}\text { Yüksek } \\
\text { B2-C1 }\end{array}$ & $\begin{array}{l}\text { Müdür (20), doktor (10), öğretmen (7), garson (3), ozan, halk şairi, futbolcu, iş adamı, } \\
\text { ayakkabı tamirciliği, oto boyacıllğı, astrolog, polis, şarkıcı, yazar, akademisyen, balıkçı, } \\
\text { manav, gazeteci, kapıcı, hâkim }\end{array}$ \\
\hline \multirow{3}{*}{ 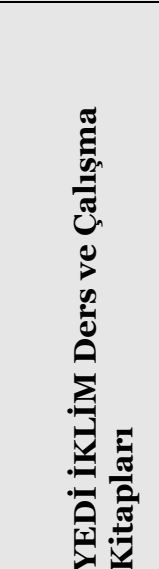 } & $\begin{array}{l}\text { Temel } \\
\text { A1- A2 }\end{array}$ & $\begin{array}{l}\text { Doktor (12), öğretmen (5), ev hanımı (3), mimar (3), terzi (3), mimar (2), şoför (2), } \\
\text { mühendis (3), pilot (2), avukat (2), polis (2), postacı, veteriner hekim, müdür, tamirci, } \\
\text { veteriner, eczacı, manav, berber, kaptan, hemşire, ressam, bilim adamı, yazar, } \\
\text { marangoz, aşç, arkeolog, bakırcı, Ramazan davulcusu, ulak, çinici, komedyen, } \\
\text { meddah, kaptan, bahçıvan, kasap, jandarma }\end{array}$ \\
\hline & $\begin{array}{l}\text { Orta } \\
\text { B1-B2 }\end{array}$ & $\begin{array}{l}\text { Mühendis (4), müdür (3), doktor (3), öğretmen, avukat, mimar, yönetici, işçi, sekreter, } \\
\text { oyuncu, şoför, yazar, sunucu, aşı pilot, tellal, hattat, zerzevatç, celepçi, nalbur, telkâri } \\
\text { ustası, halk ozanı, kitap ciltlemeciliği, çanak-çömlekçilik }\end{array}$ \\
\hline & $\begin{array}{l}\text { Yüksek } \\
\text { C1-C2 }\end{array}$ & Matrakçı \\
\hline
\end{tabular}

Tablo 5: Yabancılara Türkçe ders materyallerinde meslekler ile ilgili imajlar

Tablo 5 'te yabancllar için Türkçe materyallerinde meslekler ile ilgili imajlara yer verilmiştir. Meslekler, kültürel unsurların dışında bir imaj meselesidir. Türk insanının hangi mesleklerle yansıtıldığı uluslararası imaj açısından son derece önemlidir. Buna göre İstanbul TÖMER öğretim setinde A1, B1 ve $\mathrm{C} 1$ düzeyinde kadınların en fazla ev hanımı rolüyle betimlenmesi dikkat çekici bir bulgudur. Bunun yanı sıra kitaplarda öğretmen, banka memuru ve doktor gibi popüler mesleklere yer verilmiş olduğu da görülmektedir. İstanbul TÖMER öğretim setinde dikkat çeken bir bulgu da Ramazan davulcusu, davulcu, zurnacı, arzuhâlci gibi geleneksel mesleklere yer verilmesidir. Bunun yanı sıra Türk mutfağına ait yemeklere ilişkin meslekler de (simitçi ve kebapçı) kitaplarda kendine yer bulmuştur.

\footnotetext{
\begin{tabular}{r|l} 
Adres & Address \\
RumeliDE Dil ve Edebiyat Araştırmalar Dergisi & RumeliDE Journal of Language and Literature Studies
\end{tabular} Osmanağa Mahallesi, Mürver Çiçeği Sokak, No:14/8 Osmanağa Mahallesi, Mürver Çiçeği Sokak, No:14/8 Kadıköy - İSTANBUL / TÜRKIYE 34714 Kadıköy - ISTANBUL / TURKEY 34714 e-posta: editor@rumelide.com e-mail: editor@rumelide.com tel: +90 505 7958124, +90 2167730616 phone: +90 505 7958124, +90 2167730616
} 
Tablo 5’e göre Hitit yabancılara Türkçe öğretim setinde öğretmen, müdür ve doktor gibi popüler mesleklerin ön planda olduğu dikkat çekmektedir. Bununla birlikte Hitit öğretim setindeki temel düzey kitaplarda en fazla sırasıyla öğretmen $(\mathrm{f}=8)$, doktor $(\mathrm{f}=5)$, müdür $(\mathrm{f}=3)$; orta düzey kitaplarda en fazla sırasıyla müdür $(\mathrm{f}=14)$, doktor $(\mathrm{f}=13)$, öğretmen $(\mathrm{f}=11)$; yüksek düzey kitaplarda ise yine aynı şekilde müdür $(\mathrm{f}=20)$, doktor $(\mathrm{f}=10)$, öğretmen $(\mathrm{f}=7)$ mesleklerine yer verildiği tespit edilmiştir. Bunların dışında ise temel düzey kitaplarda kadın taksici ve erkek dadı; orta düzey kitaplarda ev hanımı ve dönerci gibi mesleklere yer verildiği dikkat çekmektedir. Yüksek düzey kitaplarda ise özellikle âşıklı geleneğini yansıtan ozan (halk şairi) gibi geleneksel ve Türk toplumuna özgü mesleklere de yer verildiği tespit edilmiştir.

Tablo 5’e göre Yedi İklim yabancılara Türkçe öğretim setinde doktor, öğretmen, mühendis gibi popüler mesleklerin ön planda olduğu dikkat çekmektedir. Bunun yanı sıra çeşit olarak temel düzey kitaplarda daha fazla mesleğe yer verildiği dikkat çekmektedir. Bunun sebebi de bu düzeyde 'meslekler' adı altında bir temaya yer verilmesidir. Bununla birlikte Yedi İklim öğretim setindeki temel düzey kitaplarda en fazla sırasıyla doktor ( $\mathrm{f}=12$ ), öğretmen $(\mathrm{f}=5)$, ev hanımı $(\mathrm{f}=3)$; orta düzey kitaplarda en fazla sırasıyla mühendis $(\mathrm{f}=4)$, müdür $(\mathrm{f}=3)$, doktor $(\mathrm{f}=3)$; yüksek düzey kitaplarda ise sadece matrakçı mesleklerine yer verildiği tespit edilmiştir. Bunların dışında ise temel düzey kitaplarda bakırcı, Ramazan davulcusu, ulak, çinici; orta düzey kitaplarda tellal, hattat, zerzevatçı, celepçi, nalbur, telkâri ustası, halk ozanı, kitap ciltlemeciliği; yüksek düzey kitaplarda ise matrakçılık gibi geleneksel ve Türk toplumuna özgü mesleklere de yer verildiği tespit edilmiştir. Kitapta bu meslekler kültürel unsurun bir parçası olarak yansıtılmış, günümüzde ise bu mesleklerin yaşamadığı vurgulanmıştır. Türkçeyi yabancı dil olarak öğrenen öğrencilere bu sayede kendi kültürlerindeki ilginç, geleneksel ve artık yaşamayan mesleklere de örnek vermeleri istenmiştir.

\begin{tabular}{|c|c|c|c|}
\hline Yayınevi & Düzey & $\begin{array}{l}\text { Yabancilara Türkçe Ders } \\
\text { imajlar }\end{array}$ & Materyallerinde Ünlü Kişiler/Kurumlar ile ilgili \\
\hline \multirow{5}{*}{ 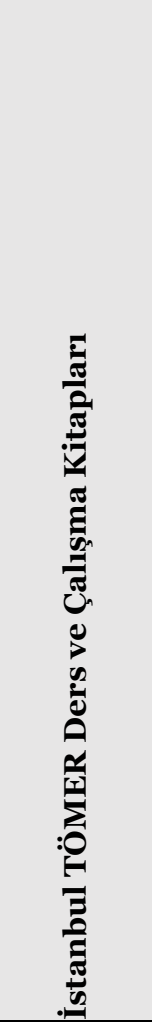 } & A1 & \multicolumn{2}{|l|}{ İbrahim Kutluay } \\
\hline & A2 & \multicolumn{2}{|c|}{$\begin{array}{l}\text { Orhan Pamuk (3), Nasreddin Hoca (3), Tarkan (2), Temel (2), Lokman Hekim, Keloğlan, } \\
\text { Yaşar Kemal, Dr. Mehmet Öz, Fatih Sultan Mehmet, Prof. Dr. Sema Aydoğdu, Hezarfen } \\
\text { Ahmet Çelebi, Atatürk, İlber Ortayl, Ebru Gündeş, Sezen Aksu, Tarık Akan, Hülya } \\
\text { Avşar, Münir Nurettin Selçuk }\end{array}$} \\
\hline & B1 & \multicolumn{2}{|c|}{$\begin{array}{l}\text { Tevfik Fikret, Ahmet Haşim, Okan Bayülgen, Çetin Altan, Barış Manço, Tahsin Yücel, } \\
\text { Haldun Dormen, Vahap Küçük (iş adamı), Güler Sabancı, Hamdi Ulukaya (iş adamı), } \\
\text { Sezen Aksu, Nina Ergin (akademisyen) }\end{array}$} \\
\hline & B2 & \multicolumn{2}{|c|}{$\begin{array}{l}\text { Tarkan (2), Mimar Sinan (2), Piri Reis, Elif Şafak, Cengiz Abazoğlu, Hakan Vardar (iş } \\
\text { adamı), Mimar Hayreddin, Evliya Çelebi, Türk Dil Kurumu, Sultan IV. Mehmet, Sunay } \\
\text { Akın, Erzurumlu İbrahim Hakkı, Mihrimah Sultan, Hürrem Sultan, Kanuni Sultan } \\
\text { Süleyman, Karagöz ve Hacivat }\end{array}$} \\
\hline & $\mathrm{C1}+$ & \multicolumn{2}{|c|}{$\begin{array}{l}\text { Atatürk (3), Yunus Emre (3), Nazım Hikmet (3), Mehmet Akif Ersoy (2), Cemal Süreya } \\
\text { (2), Hülya Koçyiğit (2), Türkan Şoray (2), Mevlâna (2), Piraye, Kanuni Sultan Süleyman, } \\
\text { II. Abdülhamit, Fuzuli, Âşık Veysel, İlhan Berk, Hilmi Yavuz, Atilla İlhan, Ahmet Arif, } \\
\text { Yahya Kemal, Orhan Pamuk, Farabi, Mimar Sinan, Avni Erbaş (ressam), Prof. Dr. Tülin } \\
\text { Günşen (akademisyen-sosyolog), Münir Özkul, Vedat Ar (yönetmen), Muhsin Ertuğrul, } \\
\text { Tarı Akan, Ertem Eğilmez, İsmail Dümbüllü, Ferhan Şensoy, Suat Kılıç (T. C. Gençlik } \\
\text { ve Spor Bakanı), Özdemir Asaf, Cengiz Dağcı, Hürrem Sultan, Latife Hanım, Kenan } \\
\text { Kalecikli (şair), Cengiz Aytmatov, Hasan Kaçan, Sultan Abdülaziz, Fatih Sultan Mehmet, } \\
\text { Sezai Karakoç, Metin Erksan (yönetmen), Ayhan Işık, Fatih Akın (yönetmen), Şener Şen, } \\
\text { Sulhi Dölek (senarist), Necip Fazıl Kısakürek, Şemseddin Tebrizi, Cemil Meriç, Setenay }\end{array}$} \\
\hline \multicolumn{4}{|c|}{$\begin{array}{r}\text { Adres } \\
\text { RumeliDE Dil ve Edebiyat Arașturmaları Dergisi } \\
\text { Osmanağa Mahallesi, Mürver Ciçĕi Sokak, No:14/8 } \\
\text { Kadıöy - İSTANBUL / TÜRKiYE 34714 } \\
\text { e-posta: editor@rumelide.com } \\
\text { tel: +90 } 5057958124,+90216773 \text { o } 616\end{array}$} \\
\hline
\end{tabular}




\begin{tabular}{|c|c|c|}
\hline & & $\begin{array}{l}\text { Alpsoy (ressam), Yıldız Kenter, Hilmi Yavuz, Talat Halman, Nasrettin Hoca, Karagöz- } \\
\text { Hacivat, Reşat Nuri Güntekin, Prof. Dr. Aydın Sayılı, Fatma Aliye Hanım, Cahit Arf, } \\
\text { Mimar Kemalettin, Muazzez İlmiye Çı̆̆g, Nurullah Ataç }\end{array}$ \\
\hline \multirow{3}{*}{ 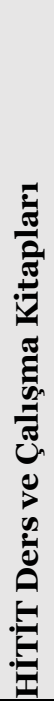 } & $\begin{array}{l}\text { Temel } \\
\text { A1-A2 }\end{array}$ & $\begin{array}{l}\text { Tarkan (2), Yıldız Kenter, Müşfik Kenter, Coşkun Aral (yazar), Osman Müftüoğlu, Hülya } \\
\text { Avşar, Cem Yılmaz, İbrahim Tatlıses, Ece Temelkuran, Atatürk }\end{array}$ \\
\hline & $\begin{array}{l}\text { Orta } \\
\text { B1 }\end{array}$ & $\begin{array}{l}\text { Sezen Aksu (4), Tarkan (3), Cem Yılmaz (2), İbrahim Kutluay (2), Rahmi Koç, Cem } \\
\text { Öğretir, Abdullah Oğuz, Emre Yurdakul (ralli pilotu), Yalvaç Ural, Balçiçek Pamir, Tunç } \\
\text { Dindaş (grafiti sanatçısı), Genco Erkal, Mustafa Erdoğan, Zihni Sinir, Van kedisi, Fuat } \\
\text { Uzkınay (yönetmen), Vildan Atasever, Beste Bereket, Ulaş İnaç (yönetmen), Nurgül } \\
\text { Yeşilçay, Meltem Cumbul, Fatih Akın, Necati Cumall, Hayko Cepkin, Ergüder Yoldaş, } \\
\text { (müzisyen), Ahmet Bedevi (Manisa Tarzanı), Kemal Sunal, Yaşar Kemal, Mimar Sinan, } \\
\text { Fatih Sultan Mehmet, Hezarfen Ahmet Çelebi, Muhsin Ertuğrul, Sedat Simavi, Türkan } \\
\text { Şoray, Yavuz Turgul, Yılmaz Erdoğan, Adile Naşit }\end{array}$ \\
\hline & $\begin{array}{l}\text { Yüksek } \\
\text { B2-C1 }\end{array}$ & $\begin{array}{l}\text { Cem Yılmaz (3), Tarkan, Yaşar Kemal, Ahmet Altan, Duygu Asena, Ece Vahapoğlu, } \\
\text { Moğollar, Sezen Aksu, Orhan Gencebay, Fatih Akı, Gani Müjde, Hakan Kırkoğlu } \\
\text { (astrolog), İpek Ongun, Yavuz Sultan Selim, Leyla Gencer (opera sanatçısı), Yavuz } \\
\text { Seçkin (komedyen) }\end{array}$ \\
\hline \multirow[b]{3}{*}{ 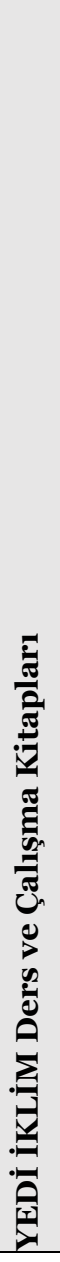 } & $\begin{array}{l}\text { Temel } \\
\text { A1- A2 }\end{array}$ & $\begin{array}{l}\text { Nasrettin Hoca (3), Cem Yılmaz (3), Fatih Sultan Mehmet (2), Yunus Emre (2), Ata } \\
\text { Demirer (2), Barış Manço (2), Şener Şen (2), Mevlâna (2), Asşı Veysel, Tarkan, Nene } \\
\text { Hatun, Sezen Aksu, Keloğlan, Ak Şemseddin, Hacı Bayram Veli, Eşref Armağan (kör } \\
\text { ressam), Kenan Sofuoğlu, Mustafa Kutlu, Kıraç, Arda Turan, Mimar Sinan, Hacı Bektaş } \\
\text { Veli, Azra Akın, Oğuz Atay, Türkan Şoray, Kadir İnanır, Adile Naşit, Münir Özkul, Yavuz } \\
\text { Turgul, Göksel, Kemal Sunal, Zeki Alasya, Metin Akpınar, Nasuh Mahruki, Şenol Güneş, } \\
\text { Karagöz-Hacivat, Atatürk, Yusuf Has Hacip, Ahmet Yesevi, Kaşgarlı Mahmut, Servet } \\
\text { Tazegül (tekvando dünya şampiyonu), Türk Hava Yolları }\end{array}$ \\
\hline & $\begin{array}{l}\text { Orta } \\
\text { B1-B2 }\end{array}$ & $\begin{array}{l}\text { Yunus Emre Enstitüsü (7), Kaşgarlı Mahmut (2), Neşet Ertaş (2), Âşılk Veysel (2), Ethem } \\
\text { Çalışkan (hat sanatçısı), Sibel Can, Yusuf Has Hacip, Yunus Emre, Eşref Armağan (kör } \\
\text { ressam), Türkan Şoray, Kartal Tibet, Ercişli Emrah, Atatürk, TBMM, Ayşe Kulin, İdil } \\
\text { Biret, Münir Özkul, Adile Naşit, İshak Alaton, Asım Kibar, Rahmi Koç, Sakıp Sabancı, } \\
\text { Saffet Ulusoy, Ahmet Yesevi, Mevlâna, İbni Sina, Mimar Sinan, Kanuni, Sultan Selim, } \\
\text { Hezarfen Ahmet Çelebi, Evliya Çelebi, Erden Aruç (yüzme şampiyonu), Gürkan Genç } \\
\text { (tur bisikletçileri dünya şampiyonu), Cemil Meriç, Hüsnü Özyeğin (iş adamı), Hasan } \\
\text { Kınalı (millî atlet) }\end{array}$ \\
\hline & $\begin{array}{l}\text { Yüksek } \\
\text { C1-C2 }\end{array}$ & $\begin{array}{l}\text { Yunus Emre (8), Yunus Emre Enstitüsü (5), Nasrettin Hoca (4), Fatih Sultan Mehmet } \\
\text { (2), Atatürk (2), Tapduk Emre (2), Hamza Yerlikaya, Elvan Abeylessege, Naim } \\
\text { Süleymanoğlu, Arda Turan, Nihat Kahveci, Tuncay Şanl,, Evliya Çelebi, M. Akif Ersoy, } \\
\text { Yavuz Sultan Selim, Neyzen Tevfik, Cem Sultan, II. Beyazıt, Baki, Fuzuli, Tahsin } \\
\text { Banguoğlu, Kemal Karpat, Âşı Şeref Taşlıva, Abdürrahim Karakoç, Necip Fazıl, Nuri } \\
\text { Pakdil, Cahit Zarifoğlu, Erdem Beyazıt, Sezai Karakoç, Cenap Şehabettin, Mevlâna, } \\
\text { Peyami Safa, Ümit Yaşar Oğuzcan, Bilge Kağan, Tonyukuk, Kültigin, Kaşgarlı Mahmut, } \\
\text { Ali Kuşçu, Uluğ Bey, Hayati Develi, Naci Avcı, Hulusi Behçet (bilim adamı), Harezmi, } \\
\text { Cahit Arf, Oğuz Atay, Barış Manço, Turan Oflazoğlu, İsmail Dede Efendi, Cengiz } \\
\text { Aytmatov, Bestami Yazgan, Can Yücel, Neyzen Tevfik, Namdar Rahmi Karatay (şair), } \\
\text { Şair Esref, Âşı Veysel, Ruhsatî, Türkan Şoray, Yahya Kemal, Ahmet Haşim, Alaaddin } \\
\text { Keykubat, Evliya Çelebi, Orhan Gazi, Mevlana, Şemsi Tebrizi, Gevher Hatun, Mikrimin } \\
\text { Halil Yınanç (bilim adamı), Hilmi Ziya Ülken, Behçet Necatigil, Üstün Dökmen, Attila } \\
\text { İlhan, Özdemir Asaf, Cahit Sıtkı Tarancl, Ahmet Muhip Dıranas, Tarlk Dursun K., Oktay } \\
\text { Akbal, Orhan Veli Kanık, Faruk Nafiz Çamlıbel, TRT, Van Kedisi, Kelaynak kuşu }\end{array}$ \\
\hline
\end{tabular}

Tablo 6: Yabancllara Türkçe ders materyallerinde ünlüler ile ilgili imajlar

Adres RumeliDE Dil ve Edebiyat Araşturmaları Dergisi Osmanağa Mahallesi, Mürver Ciçeği Sokak, No:14/8 Kadıköy - ISTANBUL / TÜRKIYE 34714 e-posta: editor@rumelide.com tel: +90 505 7958124, +90 2167730616
Address

RumeliDE Journal of Language and Literature Studies Osmanağa Mahallesi, Mürver Çiçeği Sokak, No:14/8

Kadıköy - ISTANBUL / TURKEY 34714

e-mail: editor@rumelide.com

phone: +90 $5057958124,+902167730616$ 
Tablo 6'da yabancılar için Türkçe öğretim setlerinde ünlü kişiler ya da kurumlar ile ilgili imajlara yer verilmiştir. Buna göre Yedi İklim öğretim setinin diğer kitaplara göre daha fazla sayıda ve çeşitte ünlü kişi ve kuruma yer verdiği dikkat çekmektedir. İstanbul TÖMER öğretim setinde A2 düzeyinde Orhan Pamuk ( $\mathrm{f}=3$ ) ve Nasrettin Hoca ( $\mathrm{f}=3$ ), B2 düzeyinde Tarkan ( $\mathrm{f}=2$ ) ve Mimar Sinan $(\mathrm{f}=2), \mathrm{C} 1$ düzeyinde ise Atatürk $(\mathrm{f}=3$ ), Yunus Emre $(\mathrm{f}=3$ ) ve Nazım Hikmet $(\mathrm{f}=3$ ) en çok bahsedilen ünlüler olarak yer almaktadır. Bunun yanı sıra A1 düzeyinde sadece bir ünlü kişiye (İbrahim Kutluay) yer verilmesi dikkat çekici bir bulgudur. Bununla birlikte öğretim seti genel olarak değerlendirildiğince C1 düzeyindeki materyallerde daha fazla sayıda ünlü isme yer verildiği dikkat çekmektedir. Ayrıca materyallerde yazarlardan oyunculara (Orhan Pamuk, Yaşar Kemal, Hülya Koçyiğit, Türkan Şoray vb.), tarihteki önemli şahsiyetlerden şarkıcılara (Kanuni, Fatih, Mihrimah Sultan, Ebru Gündeş, Sezen Aksu vb.), akademisyenlerden iş insanlarına (İlber Ortaylı, Mehmet Öz, Güler Sabancı, Hamdi Ulukaya vb.) kadar geniş bir yelpazede ünlü isimlere yer verildiği söylenebilir. Ünlü bir kurum olarak ise sadece B2 düzeyi ders materyallerinde Türk Dil Kurumu'na yer verildiği görülmektedir.

Diğer öğretim setleriyle kıyaslandığında Hitit ders materyallerinin ünlü isimler/kurumlar ile ilgili daha az sayıda imaja yer verdiği dikkat çekmektedir. Öğretim seti incelendiğinde ise en fazla ünlü isim/kurumlarla ilgili imaja orta düzey (B1) ders materyallerinde yer verildiği görülmektedir. Buna göre öğretim setinde temel düzeyde (A1- A2) Tarkan ( $f=2$ ), orta düzeyde (B1) Sezen Aksu ( $f=4)$, yüksek düzeyde (B2- $\mathrm{C} 1$ ) ise Cem Yılmaz ( $\mathrm{f}=3$ ) en çok ismi geçen ünlüler olarak yer almaktadır. Bununla birlikte öğretim seti genel olarak değerlendirildiğinde yazarlar (Coşkun Aral, Ece Temelkuran, Yalvaç Ural vb.), oyuncular (Kemal Sunal, Yıldız Kenter, Müşfik Kenter, Beste Bereket, Nurgül Yeşilçay, Meltem Cumbul vb.), tarihteki önemli şahsiyetler (Atatürk, Mimar Sinan, Fatih Sultan Mehmet, Hezarfen Ahmet Çelebi, Yavuz Sultan Selim vb.), şarkıcılar (Tarkan, İbrahim Tatlıses, Orhan Gencebay, Moğollar vb.), yönetmenler (Yavuz Turgul, Muhsin Ertuğrul vb.), sporcular (Emre Yurdakul), sanatçllar (Tunç Dindaş, Leyla Gencer) kitapta bahsedilen ünlü isimler olarak karşımıza çımaktadır. Bunun yanı sıra B1 düzey kitaplarda bahsedilen hayalî karakter Zihni Sinir ve Van kedisi de diğer ünlüler olarak karşımıza çıkmaktadır.

Tablo 6'da Yedi İklim yabancllar için Türkçe öğretim seti incelendiğinde en fazla ünlü isme ve kuruma yüksek düzey ders materyallerinde yer verildiği dikkat çekmektedir. Bununla birlikte öğretim setinde temel düzeyde (A1 ve A2) Nasrettin Hoca ( $\mathrm{f}=3$ ), Cem Yllmaz ( $\mathrm{f}=3$ ), Fatih Sultan Mehmet ( $\mathrm{f}=2$ ), Yunus Emre ( $f=2)$, Ata Demirer ( $f=2)$, Barış Manço ( $f=2)$, Şener Şen ( $f=2)$, Mevlâna ( $f=2)$; orta seviyede (B1 ve B2) Yunus Emre Enstitüsü ( $\mathrm{f}=4)$, Kaşgarlı Mahmut ( $\mathrm{f}=2)$, Neşet Ertaş ( $\mathrm{f}=2)$, Âşı Veysel $(\mathrm{f}=2)$; yüksek düzeyde ( $\mathrm{C} 1$ ve $\mathrm{C} 2$ ) Yunus Emre $(\mathrm{f}=8)$, Yunus Emre Enstitüsü $(\mathrm{f}=5)$, Nasrettin Hoca $(\mathrm{f}=4)$, Orhan Pamuk ( $\mathrm{f}=3$ ) ve Nasrettin Hoca $(\mathrm{f}=3)$ en çok bahsedilen ünlü isimler/kurumlar olarak yer almaktadır. Bunların dışında öğretim setinde genel olarak edebiyatçlar (Attila İlhan, Özdemir Asaf, Cahit Sıtkı Tarancı, Ahmet Muhip Dıranas, Tarık Dursun K., Oktay Akbal, Orhan Veli Kanık, Faruk Nafiz Çamlıbel), iş insanları (Hüsnü Özyeğin, İshak Alaton, Asım Kibar, Rahmi Koç, Sakıp Sabancı, Saffet Ulusoy), bilim insanları (Mikrimin Halil Yınanç, Uluğ Bey, Ali Kuşçu, Hulusi Behçet, Harezmi vb.), tarihî şahsiyetler (Atatürk, Bilge Kağan, Tonyukuk, Kültigin, Kaşgarlı Mahmut), sanatçllar (Eşref Armağan, Ethem Çalışkan), mutasavviflar (Yunus Emre, Mevlâna), sporcular (Hamza Yerlikaya, Naim Süleymanoğlu, Arda Turan, Tuncay Şanlı vb.) ve ünlü hayvanlar (kelaynak kuşu, Van kedisi) yer almaktadir.

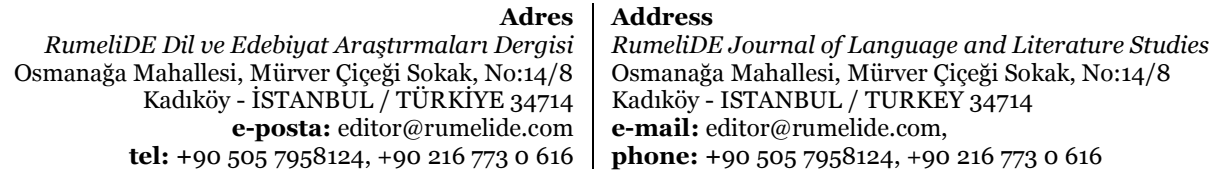

tel: +90 505 7958124, +90 2167730616 


\begin{tabular}{|l|l}
\hline & $\begin{array}{l}\text { Çiçek Festivali (İzmir), Altın Portakal Film Festivali. Edebiyat: Tercüman-ı Ahval } \\
\text { Gazetesi, Divan ü Lügati’t Türk, Seyahatnâme, Tahir ile Zühre hikâyesi, Emrah ile } \\
\text { Selvihan hikâyesi, Kazan Doğurdu (Nasrettin Hoca fikrası), Memleket İsterim (C. Sitkı } \\
\text { Tarancı) }\end{array}$ \\
\cline { 2 - 3 } Yüksek & $\begin{array}{l}\text { Edebiyat: Karagöz Hacivat oyunu (2), Seyahatnâme, Mona Rosa (Sezai Karakoç), } \\
\text { Türküler Dolusu (Bedri Rahmi Eyüpoğlu), Bir Bilim Adamının Romanı, Mesnevi, Sevi } \\
\text { Çiiri (Ümit Yaşar), Sevelim Sevilelim (Yunus Emre), Hoca'nın Hesabı (Nasrettin Hoca } \\
\text { fikrası), Hakk'n Kandilinde Gizli Sır İdim (Karacaoğlan), Karacaoğlan Türkmen şöleni, } \\
\text { Vermeyince Mabut Neylesin Mahmut, kuyafetnâmeler, taşlamalar }\end{array}$ \\
\hline
\end{tabular}

Tablo 7: Yabancılara Türkçe ders materyallerinde edebiyat/sanat/spor ile ilgili imajlar

Tablo 7'de yabancılar için Türkçe öğretim setlerinde edebiyat, sanat ve spor ile ilgili imajlara yer verilmiştir. Buna göre İstanbul TÖMER öğretim setinin diğer kitaplara göre daha fazla sayıda edebiyat/sanat ve sporla ilgili imajlara yer verdiği dikkat çekmektedir. İstanbul TÖMER öğretim setinde A1 düzeyinde hiçbir imaja rastlanmamış olması da dikkat çekici bir bulgudur. Ayrıca A2 düzeyinde en çok Galatasaray futbol takımına, B1 ve B2 düzeyinde ise Fenerbahçe futbol takımına yer verilmesi dikkat çekicidir. A2 düzeyinde edebiyat ile ilgili Gelin Kayası efsanesi, Keloğlan masalı, Bir İstanbul Efsanesi, Eşeğin Sözü (Nasrettin Hoca fikrası), Çalıkuşu romanı, Karagöz ve Hacivat; sanat ile ilgili Zeybek oyunu, İstanbul Film Festivali gibi imajlara yer verilmiştir. Aynı öğretim setinin kitaplarına bakıldığında sanat ve edebiyat ile ilgili en çok unsura $\mathrm{C} 1$ düzeyi ders materyallerinde yer verildiği dikkat çekmektedir. Buna göre sanatla ilgili unsurlar içinde diziler ve filmler ön sirada yer almaktadır. Film festivalleri, edebî türler, geleneksel el sanatları (ebru, tezhip, hat, minyatür) da sanatla ilgili imajlar olarak kitaplarda yer almaktadır. Aynı kitapta edebiyat ile ilgili imajlara bakıldığında halk hikâyeleri, Nasrettin Hoca fikraları ve kıssaların yanı sıra Mona Rosa (Sezai Karakoç), Çile (Necip Fazıl Kısakürek), Gül (Cemal Süreya), Kaşağı (Ömer Seyfettin), Aynalar ve Zaman (Hilmi Yavuz), Salkımsöğüt (N. Hikmet), Eloğlu (Metin Eloğlu) gibi modern Türk edebiyatına ilişkin anlatı ve eserlere de yer verilmiştir.

Tablo 7'de Hitit ders kitaplarına bakıldığında edebiyat/sanat ve spor ile ilgili unsurlara orta ve yüksek düzeydeki ders kitaplarında daha fazla yer verildiği dikkat çekmektedir. Spor ile ilgili imajlara bakıldığında futbol kulüpleri dışında orta düzey ders materyallerinde Fenerbahçe basketbol takımına da yer verildiği görülmektedir. Ayrıca temel düzey öğretim setinde ata sporu olarak bilinen güreşten bahsedilmiştir. Sanat ile ilgili unsurlar incelendiğinde ise diziler ve filmlerin ilk sırada yer aldığı dikkat çekmektedir. Bu unsurlara en çok orta düzey öğretim materyallerinde rastlanmaktadır. Altın Portakal Film Festivali (f=3), Vizontele, Acı Hayat, Halıcı Kız (ilk renkli Türk filmi), Fosforlu Cevriye, Yaşamın Kıyısında (film), Selvi Boylum Al yazmalım, Hababam Sınıfı, Kumdan İstanbul festivali, Anadolu Ateşi, halk dansları, Altın Koza Film Festivali, Emek ve Yeşilçam sineması bu imajlardandır. Edebiyat ile ilgili unsurlar ise en çok yüksek düzey ders materyallerinde yer almıştır. Kitapta edebî eserlerden (Şimdiki Çocuklar Harika, Dostlar Beni Hatırlasın, Üçüncü Şahsın Şiiri, Beyaz Gemi, Gençlik Böyledir İşte, Her Şey Sende Gizli), fikralara (Temel, Nasrettin Hoca), geleneksel halk danslarından (sirtaki, oryantal, halay, horon), türkülere, geleneksel tiyatrodan (gölge oyunu), geleneksel müzik aletlerine kadar (kemençe, tulum) geniş bir yelpazede edebiyat unsurlarına yer verilmiştir.

Tablo 7’ye göre Yedi İklim öğretim setinde edebiyat/sanat ve spor ile ilgili imajlara bakıldığında en çok unsurun temel ve orta düzey kitaplarda yer aldığı görülmektedir. Spor ile ilgili unsurlar ise sadece temel düzey ders kitaplarında yer almıştır. Buna göre futbol kulüplerinin dışında tekvando ve ata sporu cirit de spor dalları olarak kitaplarda kendine yer bulmuştur. Sanat ile ilgili imajlar ise temel ve 
orta düzey ders materyallerinde yer almıştır. Bu unsurlara bakıldığında dizi ve filmlerin oldukça önemli bir yer tuttuğu görülmektedir. Edebiyat ile ilgili unsurlara bakıldığında ise geleneksel halk hikâyelerinden fikralara kadar geniş bir yelpazede eserlere yer verildiği dikkat çekmektedir. Özellikle yüksek düzey ders kitaplarında Karagöz-Hacivat oyununa toplamda iki kez yer verilmiştir. Ayrıca kitaplarda Mona Rosa, Türküler Dolusu, Mesnevi, Sevi Şiiri, Sevelim Sevilelim gibi şiirlere, Nasrettin Hoca fikrasına, Karacaoğlan Türkmen şölenine, kıyafetname ve taşlamalara da yer verildiği dikkat çekmektedir.

\section{Sonuç ve tartışma}

Çalışmada yabancı dil olarak Türkçe öğretim setlerinde Türk ve Türkiye imajına ilişkin unsurlar altı başlık altında ele alınıp incelenmiştir: Gastronomi ile ilgili imajlar, mekân ile ilgili imajlar, kültürel unsurlar (dinî ve millî) ile ilgili imajlar, meslekler ile ilgili imajlar, ünlü kişiler/kurumlar ile ilgili imajlar, edebiyat/sanat/spor ile ilgili imajlar.

Öğretim setlerinde gastronomi ile ilgili imajlar incelendiğinde tüm kitaplarda içecek olarak çay, kahve ve ayran; yemek olarak kebap, döner, simit, mercimek çorbası, dürüm; tatlı olarak da baklava, künefe ve dondurmanın ön sıralarda yer aldığı tespit edilmiştir. Genel olarak bakıldığında ise İstanbul TÖMER ve Yedi İklim öğretim setlerinde gastronomi ile ilgili unsurlara daha fazla yer verildiği tespit edilmiştir. Buna karşllık Hitit öğretim setinde yeme-içme ile ilgili unsurlara daha az yer verilmiştir. Türk mutfağı yerli ve yabancı medyada kebap, döner, ayran, baklava, künefe ve Türk kahvesi gibi yiyecek ve içeceklerle tanıtılmaktadır (Yllmaz ve Çakıcı, 2019: 458). Dolayısıyla bu sonucun araştırmamızın sonuçlarıyla paralellik taşıdığı görülmektedir. Nitekim bu araştırmada da kebap, döner, ayran, baklava, künefe, Türk kahvesi gibi yiyecek ve içecekler, Türk kültürünü tanıtmada çokça kullanılmıştır. Günümüzde özellikle döner kebap, Türk mutfağının geleneksel bir simgesi iken bugün küresel çapta tüm dünya tarafından Türk yemeği olarak bilinmekte ve tüketilmektedir (Kuşçu Erbay, 2006). Yeni Hitit 1 öğretim setini kültürel unsurların aktarımı açısından inceleyen Bayraktar (2015), kitapta yeme-içme kültürümüze ait unsurların başarılı yansıtılamadığı, Türk mutfağının zenginliğinin yeterince ortaya konmadığı sonucuna ulaşmıştır. Ayrıca Bayraktar (2015), kitaplarda Türk kahvaltısından bahsedilmemesini bir eksiklik olarak vurgulamış; kola ve bira türü içecekler dışında çay, Türk kahvesi ve ayrana, evrensel fastfood kültürünün yanında simit ve dönere, pizzanın yanında pide ve kebap gibi temel beslenme şekillerine yer verilmemiş olmasını da eleştirmiştir. Aksoy (2011) da çalışmasında Yeni Hitit ders kitaplarında Türk mutfağının daha çok et ile tanıtıldığı ve geleneksel yemeklere az yer verildiğini tespit etmiştir. Benzer şekilde bu çalışmada da Türk mutfağının en popüler yiyecek ve içeceklerinin dışında daha az bilinen Anadolu mutfağına ait geleneksel yemeklere ya da içeceklere çok az yer verildiği tespit edilmiştir. Bu durum, bir eksiklik olarak karşımıza çıkmaktadır. Anadolu mutfağına has yemeklere (tarhana çorbası, düğün çorbası, yayla çorbası, yağlama, içli köfte, kabak çiçeği dolması, pide, Laz böreği, mısır unu helvası, pişmaniye, kadayıf, cevizli kete, sütlü Nuriye, höşmerim, Kemalpaşa tatlısı, ekmek kadayıfı, kabak tatlısı, tahinli kek, gül tatlısı, lokma tatlısı, fincan tatlısı, dilber dudağı, keşkül, sütlaç, güllaç, aşure, sarma, kefir) yalnızca Yedi İklim ders kitaplarında rastlanmış olması da dikkat çekicidir. Bu anlamda incelenen materyallerde Türk gastronomisinin doğru ve başarılı yansıtıldığını söylemek güçtür.

Yabancı dil olarak Türkçe öğretiminde Türkiye'nin bir mekân olarak hangi semtleri, şehirleri ve bölgeleriyle anlatıldığı da son derece önemli bir husustur. Üç tarafı denizlerle çevrili ve en eski uygarlıkların yerleşim yeri konumundaki Türkiye; pek çok tarihî, turistik, dinî, kültürel mekânı da barındırmaktadır. Bu doğrultuda, incelenen öğretim setlerinin tamamında İstanbul bir kültür başkenti

\footnotetext{
\begin{tabular}{r|l} 
Adres & Address \\
RumeliDE Dil ve Edebiyat Araştırmaları Dergisi & RumeliDE Journal of Language and Literature Studies
\end{tabular} Osmanağa Mahallesi, Mürver Çiçeği Sokak, No:14/8 $\quad$ Osmanağa Mahallesi, Mürver Çiçeği Sokak, No:14/8 Kadıköy - İSTANBUL / TÜRKIYE 34714 Kadıköy - ISTANBUL / TURKEY 34714 e-posta: editor@rumelide.com e-mail: editor@rumelide.com, tel: +90 505 7958124, +90 2167730616 phone: +90 505 7958124, +90 2167730616
} 
olarak semtleri ve tarihî/kültürel/turistik mekânlarıyla en çok bahsedilen şehir olmuştur. Bununla birlikte genel olarak yabancı dil Türkçe ders kitaplarında mekân ile ilgili unsurlara bakıldığında İstanbul, Ankara, İzmir gibi büyük şehirlere daha fazla yer verildiği dikkat çekmektedir. Ders kitaplarında genel olarak tarihî, popüler ve turistik mekânlara daha çok yer verildiği de görülmektedir. İstanbul TÖMER öğretim setinde diğer kitaplara göre daha fazla sayıda ve çeşitte mekâna yer verildiği dikkat çekmektedir. Ayrıca bu öğretim setinde İstanbul, semtleriyle birlikte en çok yer verilen mekânlardan olmuştur. İstanbul'u Ankara, Antalya ve İzmir takip etmektedir. Kitapta büyük şehirler dışında Kapadokya, Van Gölü, Yerebatan Sarnıcı, Kapalıçarşı, Sultanahmet, İstanbul Boğazı, Mevlâna Türbesi, Anadolu Hisarı, Topkapı Sarayı, İstiklâl Caddesi, Peri Bacaları, Kız Kulesi, Efes, Aya Yogi Kilisesi gibi tarihî ve turistik mekânlara da yer verilmiştir. Bu mekânların yanı sıra İzmir, Ağva, Kuşadası, Cunda, Uludağ, Bodrum, Adalar, Pamukkale, Fethiye, Yalova, Marmaris gibi popüler tatil beldelerine de geniş oranda yer verilmiştir. Hitit öğretim setinde ise diğer yayınevlerine göre daha az sayıda mekân yer almaktadır. Bu kitaplarda İstanbul ve Ankara, en çok adı geçen iki şehir olarak karşımıza çıkmaktadır. Bunun yanı sıra A1 ve A2 düzeyi kitaplarda diğer düzeylere göre daha fazla sayıda mekâna yer verildiği dikkat çekmektedir. Ankara, İstanbul, Antalya ve İzmir bu öğretim setinde en çok yer verilen mekânlardandır. Bu sonuca benzer şekilde Bayraktar (2015), Hitit 1 temel seviye kitaplarını incelediği çalışmasında İstanbul başta olmak üzere turizm açısından önemli birkaç bölge dışında değişik mekâna yer verilmediği sonucuna ulaşmıştır. Bu doğrultuda Hitit öğretim setinin diğer kitaplara göre daha zayıf kaldığını söylemek mümkündür. Aksoy (2011) ise, çalışmasında Yeni Hitit öğretim setinde mekân olarak en çok İstanbul'a yer verildiğini, Türkiye'nin tarihî ve turistik mekanlarının bir çeşitlilik içinde aktarıldığını tespit etmiştir. Bu araştırmada Yedi İklim öğretim setinde ise temel seviyede daha fazla sayıda mekâna yer verildiği tespit edilmiştir. Buna göre İstanbul, Ankara, Antalya, Edirne ve İzmir kitaplarda en çok kullanılan mekânlar olarak dikkat çekmektedir. Ayrıca son zamanlarda keşfedilen ve dünya kültür mirasına alınan en eski yerleşim yeri Göbeklitepe’ye hiçbir kitapta mekân olarak yer verilmemiş olması da dikkat çekicidir. Bununla birlikte incelenen öğretim setlerinde daha çok turistik, tarihî ve popüler mekanlara yer verildiği; bölge olarak Doğu ve Güneydoğu Anadolu'ya ait mekânlara hemen hemen hiç yer verilmediğini söylemek mümkündür. Bu sonuca benzer şekilde Ökten ve Kavanoz da (2014) yabancı dil olarak Türkçe ders kitaplarında yer alan coğrafyaya ait unsurların turistik bir gezi rehberi anlayışıyla hazırlandığını, millî kimliği göz ardı ettiğini ve sadece belli bölgeleri yansıttığını tespit etmişlerdir.

Yabancı dil olarak Türkçe ders materyallerinde kültürel unsurlarla ilgili imajlara bakıldığında misafirperverlik, millî bayramlar/günler ve dinî bayramlar/günler ile ilgili unsurların daha sık yer aldığı görülmektedir. Bu doğrultuda genel olarak kültürel unsurlara daha çok yer verilmesi gerektiği söylenebilir. İstanbul TÖMER öğretim setinde A1 düzeyinde en çok geniş aile, A2 düzeyinde en çok futbol oynamak/izlemek, B1 ve C1 düzeyinde en çok misafirperverlik, B2 düzeyinde en çok cami ile ilgili kültürel imajlar kullanılmıştır. Okur ve Keskin (2013), İstanbul TÖMER öğretim setinin temel seviye kitaplarında kültürel ögelerden daha az yararlanıldığını, orta seviye ders kitaplarında ise bu ögelere daha fazla yer verildiğini tespit etmiştir. Benzer şekilde Mutlu ve Set (2020) ile Erdem, Gün ve Karateke (2015) İstanbul TÖMER ileri düzey (C1) ders kitaplarında kültürel unsurların yoğun olarak kullanıldığını tespit etmişlerdir. Oysa bu araştırmada seviye ilerledikçe kültürel unsurlara daha fazla yer verildiğini söylemek mümkün değildir. Aksine incelenen kitaplarda kültürel ögelerin seviyelere göre dengeli bir artış ya da azalış göstermediği görülmektedir. Bu sonuca benzer olarak Sever de (2019), Yedi İklim ve Yeni Hitit ders kitaplarında seviye arttıkça kültürel öge sayısının azaldığını tespit etmiştir. Hitit öğretim setine bakıldı̆̆ında ise temel seviyede piknik yapmak, orta seviyede millî bayramlar/günler ve yüksek seviyede misafirperverlik ile ilgili imajlara çokça yer verildiği dikkat çekmektedir. Yılmaz (2012) Hitit ders kitaplarını kültür aktarımı açısından incelediği çalışmasında söz 
konusu kitapların birçok kültürel öge içerdiğini ve Türk kültürünü başarıyla yansıttığını tespit etmiştir. Oysa Bayraktar (2015), Yeni Hitit 1 temel seviye ders kitabının kültürel unsurları aktarmada yetersiz olduğunu ve kitapta toplumsal yaşamın bütününün yansıtılmadığını tespit etmiştir. Akçaoğlu (2017) ve Sever (2019) ise, Yedi İklim öğretim setinde, kültürel unsurlara Yeni Hitit öğretim setine göre daha fazla yer verildiğini tespit etmişlerdir. Bu araştırmada ise Yedi İklim öğretim setinde namaz kılmak, misafirperverlik ve geleneksel ev mimarisi ile ilgili kültürel imajların çokça yer aldığı belirlenmiştir. Misafirperverlik ile ilgili olarak tüm kitaplarda misafir odası, misafir ağırlama, kolonya ve şeker ikram etme, misafir sofrası gibi kavramlara çokça yer verildiği dikkat çekmektedir. Ayrıca Türk âdetlerinden kız isteme ritüeli de düğün merasimi, yüz görümlüğü, davul-zurna, gelin çıkarma, beşibiryerde, kına gecesi, tuzlu kahve ikram etme, bir yastıkta kocama, küstüm yastı̆̆ı, takı merasimi gibi imajlarla anlatılmıştır. Millî bayramlara ilişkin imajlar da 29 Ekim, 23 Nisan, 19 Mayıs, 30 Ağustos, 9 Eylül ve Nevruz Bayramı gibi unsurlarla anlatılmıştır. Dinî bayramlar/günler ile ilgili imajlar da Ramazan Bayramı, arife günü, Kurban Bayramı, el öpmek, bayram ziyareti, bayram harçlı̆̆ı, kurban kesmek, bayram namazı, ezan, camiye gitmek, oruç tutmak gibi imajlarla anlatılmıştır. Bunun yanı sıra kitaplarda Türklerin komşuluk ve akrabalık ilişkilerine önem verdiği de çeşitli imajlarla vurgulanmıştır. Ökten ve Kavanoz (2014), yabancı dil olarak Türkçe öğretimini hedefleyen ders kitaplarında Türk kültürüne ait ögelerin kültürlerarası öğrenmeyi desteklemekte yetersiz kaldığı sonucuna ulaşmıştır. Kitaplarda özellikle millî kimlik olgusunun zayıf kaldığını tespit eden Ökten ve Kavanoz'a (2014) göre tarihî ve mimarî eserler, millî kimlik ile yeterince ilişkilendirilmemiş; yakın tarih ise işlenmemiştir. Buna karşllık kitaplarda millî klişeler ve sembollerde yemekler ve sanatsal nesneler ön planda tutulmuş; devlet adamları, din büyükleri ve tanınmış yazarların özlü sözlerine yer verilmiş ancak bir yabancının anlayabileceği bağlamsal kültürel içeriğe gereken önem verilmemiştir. İşci de (2012) Yeni Hitit Türkçe kitabında yer alan metin içeriklerinin Batı kültürünü temsil eder nitelikte oluşunu eleştirmiş, kitapta millî kültüre ait ögelere çok az yer verildiğini vurgulamıştır. Bu sonuçlardan farklı olarak Yılmaz da (2012) Yeni Hitit Türkçe ders kitaplarında Türk kültürüne ait ögelere yeterince yer verildiği sonucuna ulaşmıştır. Yabancı dil olarak Türkçe ders materyallerinde kültürel ögelerin ne ölçüde yer alması gerektiği ile ilgili kesin bir ölçüt olmasa da incelenen kitaplardaki kültürel aktarımın yeterli olmadığı ifade edilebilir.

Yabancılar için Türkçe ders materyallerinde meslekler ile ilgili imajlar da oldukça önemlidir. Türk insanının hangi mesleklerle yansıtıldığı uluslararası imaj açısından son derece önemli bir husustur. Yapılan araştırmalar, Türkiyeli göçmenlerin yurt dışında daha çok taksicilik, kebapçılık ve ev hanımlığı gibi meslekleri icra ettiğini göstermektedir (Sili Kalem, 2016). Oysa bu durum uluslararası imaj meselesi açısından doğru değildir. Modern Türk toplumu açısından bakıldığında kadınların ev hanımlığı dışında çalışma hayatında aktif olarak yer aldığı, erkeklerin ise kebapçılık ve taksi şoförlüğü dışında meslekleri de icra ettikleri vurgulanmalıdır. İncelenen öğretim setlerinde meslekler ile ilgili imajların doyurucu nitelikte olmadığı ifade edilebilir. Türk imajına katkısı açısından bakıldığında kitaplarda mesleklerle ilgili unsurların yeterli kullanılmadığı görülmektedir. Türklerin daha çok hangi meslek grubuyla yansıtıldığı bir kültürel imaj meselesidir. Buna göre incelenen öğretim setlerinde (özellikle İstanbul TÖMER) kadınların ev hanımı olarak sıkça yansıtıldığı görülmektedir. Bunun yanı sıra öğretmen, doktor, mühendis, banka memuru gibi popüler mesleklere yer verilmiş olduğu da görülmektedir. Yedi İklim öğretim setinde ise geleneksel Türk mesleklerinden bakırcılık, Ramazan davulculuğu, ulak, çinici, tellal, hattat, zerzevatçı, celepçi, nalbur, telkâri ustası, halk ozanı, kitap ciltlemeciliği ve matrakçllk gibi geleneksel ve Türk toplumuna özgü mesleklere de yer verilmesi oldukça önemlidir. Bu meslekler bugün her ne kadar yaşamıyor da olsa geçmişte Türk kültürüne has olmaları yönüyle önemlidir. Bu mesleklerin tanıtılmasıyla yabancı dil olarak Türkçe öğrenenlere kendi kültürlerindeki ilginç ve artık yaşamayan meslekler hatırlatılmakta ve onların iki kültür arasında ilişki 
kurmalarına da firsat tanınmaktadır. Yeni Hitit ders kitaplarında ise modern ve popüler mesleklere daha çok yer verildiği tespit edilmiş; özellikle cinsiyetçi meslek anlayışının kalmadığı kadın taksi şoförü ve erkek dadı meslekleriyle vurgulanmaya çalışılmıştır. Aksoy (2011) da Yeni Hitit ders kitaplarında Türk imgesini incelediği çalışmasında benzer sonuçlara değinmiştir.

Ünlü isimler/kurumlar ile ilgili imajlar da kültür aktarımı ve Türk imajı açısından oldukça önemlidir. Buna göre İstanbul TÖMER öğretim setinde Orhan Pamuk, Nasrettin Hoca, Tarkan, Mimar Sinan, Atatürk, Yunus Emre ve Nazım Hikmet en slk bahsedilen ünlülerdendir. Ayrıca materyallerde yazarlardan oyunculara (Orhan Pamuk, Yaşar Kemal, Hülya Koçyiğit, Türkan Şoray vb.), tarihteki önemli şahsiyetlerden şarkıcılara (Kanuni, Fatih, Mihrimah Sultan, Ebru Gündeş, Sezen Aksu vb.), akademisyenlerden iş insanlarına (İlber Ortaylı, Mehmet Öz, Güler Sabancı, Hamdi Ulukaya vb.) kadar geniş bir yelpazede ünlü isimlere yer verildiği görülmektedir. Öğretim setlerine genel olarak bakıldığında ise yüksek düzey ders materyallerinde daha fazla çeşit ve sayıda ünlü isme/kuruma yer verildiği tespit edilmiştir. Ancak genel olarak değerlendirildiğinde popüler kültür anlayışı dışında gerçekten alanına katkı sağlamış ünlü insanlara ders kitaplarında yer vermenin daha doğru olacağı düşünülmektedir.

Araştırmada edebiyat, sanat ve sporla ilgili unsurların en fazla İstanbul TÖMER C1 düzeyindeki kitaplarda yer aldığı tespit edilmiştir. Bu sonuca paralel olarak Mutlu ve Set'e göre de (2020) aynı ders kitabında en çok kullanılan kültürel unsur edebiyat, sanat ve müziktir. Ayrıca incelenen ders kitapları içerisinde Hitit yayınevine ait kitaplarda bu unsurların daha az yer aldığı görülmektedir. Bu sonuca benzer şekilde Bayraktar (2015) da araştırmasında edebiyat ve sanatla ilgili unsurların Yeni Hitit temel seviye kitaplarında yeterince yer almadığı sonucuna ulaşmıştır. Kutlu (2014), Gazi TÖMER B1 ve B2 düzeyindeki kitaplarda edebiyat ile ilgili kültürel unsurların daha çok verildiğini ancak edebî metinlerin yeterince kullanılmadığı sonucuna ulaşmıştır.

Araştırmada incelenen ders kitaplarında sanat ile ilgili unsurlardan en çok Türk dizilerine yer verildiği tespit edilmiştir. Günümüzde Türk dizilerinin Latin Amerika, Balkanlar, Ortadoğu ve Orta Asya başta olmak üzere dünya çapında yüz elliden fazla ülkede milyonlarca insan tarafından izlendiği bilinmektedir. Türkiye, özellikle son on yıldır Amerika Birleşik Devletleri’nden sonra dünyada ikinci büyük dizi ihracatçısı konumuna gelmiştir. Bu anlamda Türk dizilerinin uluslararası düzeyde büyük bir üne ulaşmış olması, Türk kültürünün ve Türkiye imajının dizilerde nasıl yansıtıldığını da belirlemek gerektiğini ortaya koymaktadır (Özarslan, 2020: 216). Bu araştırmada incelenen kitaplarda çoğunlukla tarihî dizilere yer verildiği dikkat çekmektedir.

$\mathrm{Bu}$ araştırmada incelenen ders materyallerinde spor ile ilgili unsurlara bakıldığında ise daha çok futbol üzerinde durulduğu, diğer spor türlerinin ihmal edildiği tespit edilmiştir. Özellikle İstanbul TÖMER öğretim setinde spor ile ilgili olarak sadece futbol takımlarına yer verildiği dikkat çekmektedir. Bunun yanı sıra Yeni Hitit öğretim setinde ata sporumuz olan güreşe, Yedi İklim öğretim setinde ise yine güreşe ve tekvandoya bir spor türü olarak yer verildiği belirlenmiştir. Bunun yanı sıra Yeni Hitit öğretim setinde futbol fanatizmi üzerinde durularak Türklerin maçlarda agresif ve çirkin davranışlar sergiledikleri dile getirilmiştir. Aksoy (2011) da Yeni Hitit ders kitaplarını incelediği çalışmasında olumsuz bir Türk imgesi olarak futbol fanatizmine yer verilmesinin doğru olmadığını vurgulamıştır.

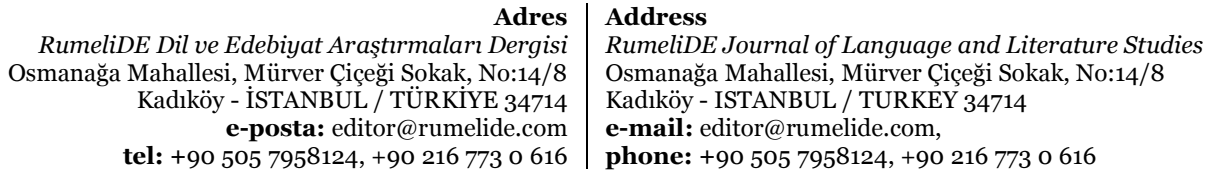

tel: +90 505 7958124, +90 2167730616 


\section{Öneriler}

Yabancı dil olarak Türkçe öğretim setlerinde Türk ve Türkiye imajının nasıl betimlendiğini ortaya koymaya çalışan bu araştırmada meslekler, mekânlar, gastronomi ve kültürel imajlarla ilgili unsurların yeterince ve kapsayıcı bir şekilde yer almadığı tespit edilmiştir. Bununla birlikte yabancı dil olarak Türkçe öğrenen öğrencilere Türk kültürünü, Türk ve Türkiye imajını sağlıklı bir şekilde yansıtmak için geleneksel Türk mesleklerine, yemeklerine, kültürel unsurlara bolca yer verilmesi gerekmektedir. Ders materyallerinin bu anlayış doğrultusunda hazırlanması oldukça önemli bir husustur. Kültürel ögelerin, Türk ve Türkiye imajının belirlenmesinde toplumsal yaşamda var olan durumlar, tarafsız bir bakış açısıyla olduğu gibi yansıtılmalı; meslekler, iş hayatı, yemek kültürümüz gibi temalar adı altında evrensel unsurlar yanında Türklüğe has ögelere de çokça yer verilmelidir.

Materyallerde Türkiye coğrafyasının her tarafına eşit oranda yer verilmeli; sadece belli büyük şehirler ve belli turistik ve popüler mekânlar yansıtılmamalıdır. Kitapların yeni baskıları yapılırken bu güncelliğe özen gösterilmelidir.

Türk gastronomisi sadece kebap, döner, lahmacun, çay ve kahve ile değil Anadolu mutfağını yansıtan daha az bilinen yiyeceklerle de temsil edilmelidir.

Türk imajını ortaya koyan meslekler tanıtılırken ev hanımlığı ve taksicilik dışında geleneksel mesleklerden de bahsedilmelidir.

Kitaplarda ünlü insanlarla ilgili imajlara bakıldığında daha çok popüler isimlere yer verildiği dikkat çekmektedir. Oysa kitaplarda edebiyat, sanat, siyaset ve sporda gerçekten alanına katkı sağlamış başarılı isimlere yer verilmesi kültür aktarımı açısından daha önemlidir.

Kültür aktarımının önemli bir boyutu da edebî eserlerdir. Dil öğretiminde kullanılan edebî eseler vasıtasıyla kültür aktarımı da gerçekleşmektedir. Özellikle yabancı dil olarak Türkçe öğretimi kitaplarında ileri seviyelerde Türk kültürünü yansıtan nitelikli edebî eserlere daha çok yer verilmelidir.

\section{Kaynakça}

Akçaoğlu, C. (2017). Somut olmayan kültürel miras ve yabancı dil olarak Türkçe öğretiminde kullanımı. Yayımlanmamış Yüksek Lisans Tezi, Ankara: Hacettepe Üniversitesi Türkiyat Araştırmaları Enstitüsü.

Akkaya, A. (2013). Yabancılara Türkçe öğretimi kapsamında fikralar: Nasreddin Hoca fikraları. Millî Folklor, 25 (100), 171-181.

Aksoy, B. (2011). Yabancı dil olarak Türkçe ders kitaplarında Türk imgesi. Yayımlanmamış Yüksek Lisans Tezi, İstanbul: İstanbul Üniversitesi Yabancı Dil Olarak Türkçe Bilim Dalı.

Bayraktar, S. (2015). Yeni Hitit 1 yabancılar için Türkçe ders kitabının kültür aktarımı açısından incelenmesi. Hacettepe Üniversitesi Yabancı Dil Olarak Türkçe Araştırmaları Dergisi, 2, 7-23.

Berg, B. L. \& Lune, H. (2015). Sosyal bilimlerde nitel araştırma yöntemleri. (Çev.: H. Aydın). Konya: Eğitim.

Bölükbaş, F. ve Keskin, F. (2010). Yabancı dil olarak Türkçe öğretiminde metinlerin kültür aktarmadaki işlevi. Turkish Studies, 5 (4), 221-235.

Byram, M. ve C. Morgan (1994). Teaching and learning language and culture. Clevedon: Multilingual Matters.

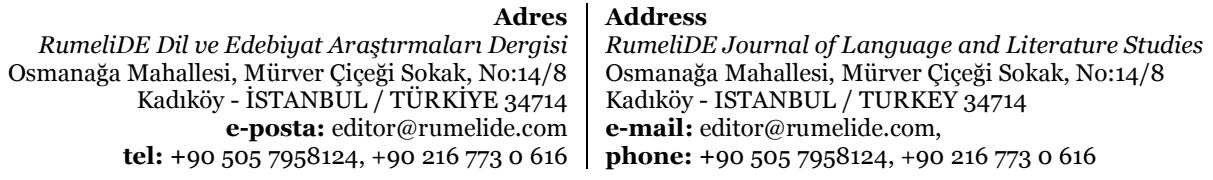

tel: +90 505 7958124, +90 2167730616 
CEFR (2020). Common european framework of reference for languages: learning, teaching, assessment companion volume with new descriptors. Council of Europe.

Cortazzi, M. \& Jin, L. (1999). Cultural mirrors: materials and methods in the efl classroom. E. Hinkel (Ed.), Culture in second langauge teaching and learning içinde (ss. 196-219). Cambridge: Cambridge Press.

Demir, A. ve Açık, F. (2011). Türkçenin yabancı dil olarak öğretiminde kültürlerarası yaklaşım ve seçilecek metinlerde bulunması gereken özellikler. Türklük Bilimi Araştırmaları, 30, 51-72.

Demircan, Ö. (1990). Yabancı dil öğretim yöntemleri. İstanbul: Dergâh.

Erdem, M., Gün, M. ve Karateke, B. (2015). İleri seviye için hazırlanan İstanbul yabancllara Türkçe öğretim setinin kültür aktarımı açısından incelenmesi. International Journal of Language Academy, 3 (1), 8-17.

Gültekin, B. (2005). Türkiye'nin uluslararası imajında yükselen değerler ve eğilimler. İletişim Dergisi, $4,126-140$.

Haley, M. H. \& Austin, T. Y. (2013). Content-based second language teaching and learning-an interactive approach. USA: Pearson Education Inc.

İşçi, C. (2012). Türkçenin yabancı dil olarak öğretiminde kullanılan yeni Hitit ders kitabının dört temel dil becerisi ve kültür açısından incelenmesi. Yayımlanmamış Yüksek Lisans Tezi, İzmir: Dokuz Eylül Üniversitesi Eğitim Bilimleri Enstitüsü.

Karababa, Z. ve Üstünsoy Taşkın, S. (2012). An evaluation of the course books for teachıng Turkish as a foreign language based on teacher opinions. Dil Dergisi, 157, 65-80.

Karagöz Yerdelen, B. (2017). Uluslararası ilişkilerde imaj kavramı ve Batı nostaljisindeki bir aksaklık olarak Türk imajı. Karadeniz, 35, 43-63.

Karasar, N. (2007). Bilimsel araştırma yöntemleri (17. baskı). Ankara: Nobel.

Kuşçu Erbay, A. (2006). Popüler kültür ve beslenme biçimleri örnek olay: döner kebap. Yayımlanmamış Yüksek Lisans Tezi, Ankara: Gazi Üniversitesi Sosyal Bilimler Enstitüsü.

Kutlu, A. (2014). Yabancılara Türkçe öğretiminde kültürün araç olarak kullanımı: Gazi yabancılar için Türkçe öğretim seti örneği (b1- b2 seviyesi). Kastamonu Eğitim Dergisi, 12 (2), 697-710.

Memiş, M. R. (2016). Yabancı dil öğretiminde eğitim ortamı ve kültür aktarımı. Turkish Studies, 11 (9), 605-616.

Merriam, S. B. (2013). Nitel araştırma desen ve uygulama için bir rehber. (Çev. Ed.: S. Turan), Ankara: Nobel.

Miles, M, B. \& Huberman, A. M. (1994). Qualitative data analysis: An expanded sourcebook. Thousand Oaks, CA: Sage.

Mutlu, H. ve Set, G. (2020). Yabancı dil olarak Türkçe öğretiminde kullanılan c1 seviye ders kitaplarındaki kültür unsurlarının incelenmesi (Gazi yabancılar için Türkçe-İstanbul yabancılar için Türkçe). Dil Dergisi, 1 (171), 91-108.

Okur, A. ve Keskin, F. (2013). Yabancılara Türkçe öğretiminde kültürel ögelerin aktarımı: İstanbul yabancllar için Türkçe öğretim seti örneği. International Journal of Social Science, 6(2), 16191640 .

Ökten, C. E. ve Kavanoz, S. (2014). Yabancı dil olarak Türkçe öğretimini hedefleyen ders kitaplarında kültür aktarımı. Turkish Studies, 9(3), 845-862.

Özarslan, K. (2020). Ülke markalaması bağlamında uluslararası basında Türk dizileri ve Türkiye imajı. Dokuz Eylül Üniversitesi Sosyal Bilimler Enstitüsü Dergisi, 22 (1), 215-238.

Özışık, C. (2004). Yabancı dil öğretiminde kültürel farkındalık: New Headway ders kitaplarının kültür aktarımı açısından incelenmesi ve değerlendirilmesi. Yayımlanmamış Yüksek Lisans Tezi, İstanbul: İstanbul Üniversitesi Sosyal Bilimler Enstitüsü.

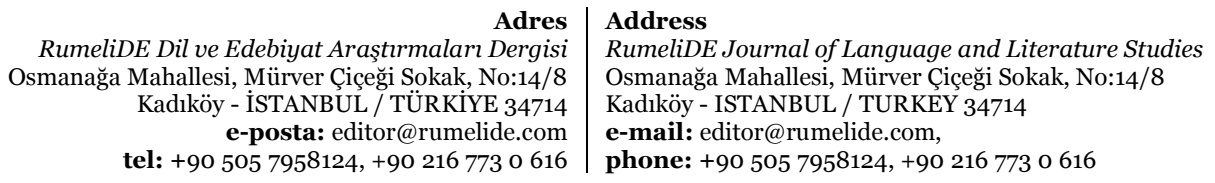


Patton, M. Q. (2014). Nitel araştırma ve değerlendirme yöntemleri. (Çev. Ed.: M. Bütün ve S. B. Demir), Ankara: PegemA.

Sever, P. (2019). Yeni Hitit dil öğretim seti ile Yedi İklim öğretim setinin Türkçenin yabancı dil olarak öğretiminde kültür aktarımı açısından karşılaştırılması. Yayımlanmamış Yüksek Lisans Tezi, Nevşehir Hacı Bektaş Veli Üniversitesi Sosyal Bilimler Enstitüsü.

Sili Kalem, A. (2016). Türk çayına süt katmak: Londra'da yaşayan Türkiyeli göçmenlerin gündelik hayatları. İnsan ve Toplum, 5(10), 43-71.

Songül, S. (1991). Hedef kültürün aktarılmasının amaçları ve öğretim teknikleri. Dil Öğretim Dergisi, 3, Ankara Üniversitesi TÖMER.

Tapan, N. (1990). Yabancı dil olarak Almanca öğretiminde kültür bağlamının değerlendirilmesi. Alman Dili ve Edebiyatı Dergisi, 7, 55-68.

Tapan, N. (1995). Yabancı dil olarak Almanca öğretiminde yeni bir yöneliş: Kültürler arası-bildirişimodaklı yaklaşım. Alman Dili ve Edebiyatı Dergisi, 9, 149-167.

TDK. (2011). Türkçe sözlük. Ankara: TDK.

Tseng, Y. H. (2002). A lesson in culture. ELT Journal, 56(1), 11-21.

Ülker, N. (2007). Hitit ders kitapları örneğinde yabancı dil olarak Türkçe öğretiminde kültür aktarımı sürecine cözümleyici ve değerlendirici bir bakış. Yayımlanmamış Yüksek Lisans Tezi, İstanbul: İstanbul Ứniversitesi Sosyal Bilimler Enstitüsü.

Wach, E. (2013). Learning about qualitative document analysis. Institute of Development Studies, 13, 1-9.

Yaylı, D. ve Yaylı, D. (2009). Yabancı dil öğretimi yaklaşımları ve yöntemleri. D. Yaylı ve Y. Bayyurt (Ed.). Yabancılara Türkçe Öğretimi: Politika, Yöntem ve Beceriler içinde (s. 7-29). Ankara: Anı.

Yıldırım, A. ve Şimşek, H. (2016). Sosyal bilimlerde nitel araştırma. Ankara: Seçkin.

Yllmaz, F. (2012). Cultural transmission through teaching Turkish as a foreign language course books. Turkish Studies, 7(3), 2751-2759.

Yılmaz, H. ve Çakıcı, H. H. (2019). Yazılı medyada Türk mutfă̆ı. Journal of Tourism and Gastronomy Studies, 7 (1), 450-462. 